\title{
Evolution of the Southwestern Angolan Margin: episodic burial and exhumation is more realistic than long-term denudation
}

\author{
Bruno Venancio da Silva ${ }^{1}$. Peter Christian Hackspacher ${ }^{1} \cdot$ Marli Carina Siqueira Ribeiro $^{1}$. \\ Ulrich Anton Glasmacher ${ }^{2}$ - Antonio Olimpio Gonçalves ${ }^{3}$. Carolina Doranti-Tiritan ${ }^{1} \cdot$ Daniel Françoso de Godoy ${ }^{1}$. \\ Renata Regina Constantino ${ }^{1}$
}

Received: 18 January 2018 / Accepted: 3 August 2018 / Published online: 13 August 2018

(c) Springer-Verlag GmbH Germany, part of Springer Nature 2018

\begin{abstract}
There are two main points of view regarding how continental margins evolve. The first one argues that the present-day margins have been developed by long-term denudation since a major exhumation episode, probably driven by rifting or another relevant tectonic event. The second one argues that continental margins underwent alternating burial and exhumation episodes related to crustal tectonic and surface uplift and subsidence. To demonstrate that the proximal domain of the southwestern Angolan margin has evolved in a polycyclic pattern, we present a review of geological and thermochronological information and integrate it with new combined apatite fission-track and (U-Th)/He data from Early Cretaceous volcanic and Precambrian basement samples. We also provide hypotheses on the possible mechanisms able to support the vertical crustal movements of this margin segment, which are also discussed based on some modern rifting models proposed for Central South Atlantic. The central apatite fission-track ages range from 120.6 \pm 8.9 to $272.9 \pm 21.6 \mathrm{Ma}$, with the mean track lengths of approximately $12 \mu \mathrm{m}$. The single-grain apatite (U-Th)/He ages vary between $52.2 \pm 1$ and $177.2 \pm 2.6 \mathrm{Ma}$. The integration of the thermochronological data set with published geological constraints supports the following time-temperature evolution: (1) heating since the Carboniferous-Permian, (2) cooling onset in the Early Jurassic, (3) heating onset in the Early Cretaceous, (4) cooling onset in the Mid- to Late Cretaceous, (5) heating onset in the Late Cretaceous, and (6) cooling onset in the Oligocene-Miocene. The thermochronological data and the geological constraints, support that the proximal domain of the southwestern Angolan margin was covered in the past by pre-, syn-, and post-rift sediments, which were eroded during succeeding exhumation events. For this margin segment, we show that a development based on long-term denudation is less realistic than one based on burial and exhumation episodes during the last $130 \mathrm{Myr}$.
\end{abstract}

Keywords Apatite fission track $\cdot(\mathrm{U}-\mathrm{Th}) / \mathrm{He} \cdot$ Namibe Basin $\cdot$ Thermal modeling $\cdot$ Thermochronology $\cdot$ Passive margin

\section{Introduction}

Understanding of the rifting process has been improved since classical models of rifting were proposed, such as the pure-shear model (McKenzie 1978), and simple-shear model (Wernicke 1985). The combined analysis of new geophysical

Bruno Venancio da Silva

rochabt@gmail.com

1 Institute of Geosciences and Exact Sciences, UNESP - São Paulo State University, Rio Claro, Brazil

2 Institute of Earth Sciences, Heidelberg University, Heidelberg, Germany

3 Faculty of Natural Sciences, Agostinho Neto University, Luanda, Angola data and thermo-mechanical modeling in some recently published research papers (Brune et al. 2014; Contrucci et al. 2004; Manatschal 2004; Péron-Pinvidic and Manatschal 2008; Strozyk et al. 2016; Torsvik et al. 2009; Whitmarsh et al. 2001) give a new overview of the rifting process, suggesting that it might be governed by a succession of complex events, characterized by different lithospheric stretching phases that vary in time and space.

Non-uniform extension processes that explore the concept of depth-dependent extension either at crustal or mantle level (Huismans and Beaumont 2014; Masini et al. 2014; Svartman Dias et al. 2016) coupled with other complex mechanisms (Ziegler and Cloetingh 2004; Reston 2009; Lentini et al. 2010; Dafoe et al. 2017) are proposed to explain the occurrence of vertical crustal movements 
related, for example, with tectonic and surface uplift of the rift flanks, with exhumation of the lithospheric mantle or lower crust in the outer margin, with development of the pre-sag unconformity in the marginal basins, and with sag to post-rift subsidence affecting the stretched lithosphere domain seaward of the hinge line.

Vertical crustal movements discussed by the new rifting models emphasizes the stretched lithosphere domain and do not focus on the vertical movements that occurs in the proximal domain. The last is classified as a less to non-stretched lithosphere domain where vertical movements related to extension and thinning during rifting (or post-rift) would be limited, although possible surface uplift of the rift flanks may be predicted (Péron-Pinvidic and Manatschal 2008; Brune et al. 2014; Huismans and Beaumont 2014).

Data worldwide contend that rift to post-rift evolution of the proximal margins might be controlled by vertical crustal movements related with events of erosion, burial, development of regional unconformities, tectonic reactivation, and magmatism (Gallagher and Brown 1999; Raab et al. 2002; Lundin and Doré 2002; Japsen et al. 2006; Mohriak et al. 2008; Tinker et al. 2008; Turner et al. 2008; Bache et al. 2011; Guillocheau et al. 2012; Franke 2013; Wu et al. 2014; Dressel et al. 2015, 2017; Bunge and Glasmacher 2018; Colli et al. 2018; Friedrich et al. 2018; Müller et al. 2018; Kukla et al. 2018). In this context, two main points of view are highlighted: (1) the evolution of the proximal margins has been driven by long-term denudation since rifting or another tectonic event (e.g., Cockburn et al. 2000; Van Der Beek et al. 2002; Kounov et al. 2009) and (2) the evolution of the proximal margins has been controlled by episodic burial and exhumation events (e.g., Japsen et al. 2006; Green et al. 2015, 2018).

The aim of this study is to show that the southwestern Angolan margin known as Namibe margin (Fig. 1) has evolved from cyclical episodes of burial and exhumation. We restore the stratigraphic response of the main vertical crustal movements that occurs during the margin development. For this purpose, a review of geological aspects is presented and integrated with previous and new thermochronological data by applying apatite fission-track (AFT) and (U-Th)/He (AHe) analysis. Bearing in mind that potential exhumation and burial events are related to crustal tectonic and surface uplift and subsidence, some modern rifting models proposed for the Central South Atlantic segment are also discussed, and we speculate some additional possible mechanisms.

\section{Geology overview}

The study area lies within the Angola block of the Congo Craton, which outcrops in the south-central portion of Angola and extends to the north of Namibia (De Waele et al. 2008). The region is characterized by Archean to
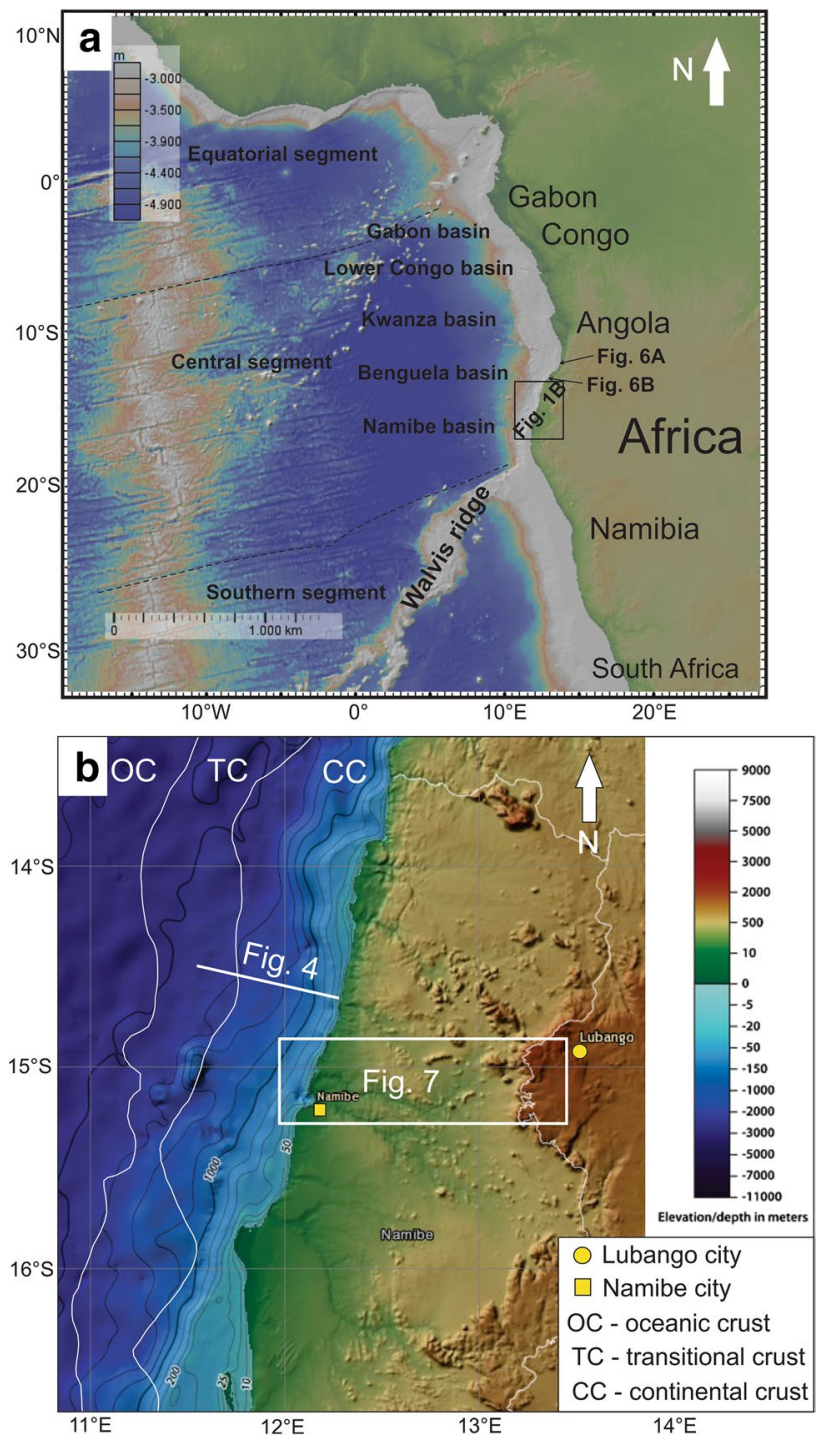

Fig. 1 a Bathymetric image of the Central South Atlantic African margin (Ryan et al. 2009) and location of the marginal basins. b Location map of the study area. White lines represent inferred boundaries between continental, transitional, and oceanic crust domains (Reid and Ashfield 2016). Note the locations of the Figs. 4 and 7

Palaeoproterozoic gneisses and granites (Araújo and Guimarães 1992). Further East, these rocks are covered unconformably by the Palaeoproterozoic volcano-sedimentary Chela Group (McCourt et al. 2013), while the South and Southwest of the Angola block are respectively surrounded by the Neoproterozoic Damara and Kaoko belts, developed during the Pan-African-Brazilian orogenic cycle (Kroner 1982; Jung and Mezger 2001; Rogers and Santosh 2004).

During the Pan-African-Brazilian orogeny, the platform and molasse sediments from the Proterozoic Damara Sequence were deposited, overlying the Pre-Cambrian basement (Miller 1997). Following the Pan-African orogenic cycle, this Sequence was affected by a long period of 
erosion, interrupted by the deposition of Karoo sediments in the Carboniferous period at approximately $300 \mathrm{Ma}$ (e.g., Johnson et al. 1996; Catuneanu et al. 2005).

The overall stratigraphic record of the Karoo Supergroup in southern Africa began with glacially deposits of the Dwyka Formation, currently recognized in basins from the South Africa to the Sudan further north. The Dwyka Group was followed by the Ecca Group, composed mostly of dark shales, siltstones, and sandstones deposited in marine, lacustrine, and deltaic environments. Following, the Beaufort Group consists mostly of fluvially deposited rocks composed of colored mudrock, sandstones, and conglomerates, which were covered by rocks of the Stormberg Group, composed by fluvial and aeolian sediments within semi-arid to arid environments (Catuneanu et al. 2005). The late stage of the Karoo sedimentation in the continent coincides with the extrusion of the Drakensberg basalts at $\sim 180 \mathrm{Ma}$ (Moulin et al. 2017) related to the onset of Gondwana breakup processes.

In northwest Namibia, the Stormberg Group was overlaid unconformably by the Cretaceous Etendeka Group, composed by the Twyfelfontein, Awahab, Tafelberg, and Etendeka Formations, in the Huab Basin (Fig. 2) (Marsh and Milner 2007). The Twyfelfontein Fm. is composed from base to top by fluvial, fluvial-aeolian, and Aeolian deposits that record a change from semi-arid to extremely arid conditions (Porchetti and Wagensommer 2015). Those Aeolian deposits exhibit lateral changes with the Etendeka basalts (Porchetti and Wagensommer 2015) dated in $\sim 132 \mathrm{Ma}$ (Renne et al. 1996). The Etendeka volcanics have been considered as the last expression of the Karoo volcanism (Drakensberg Gr.) (e.g., Eales et al. 1984; Catuneanu et al. 2005), and are associated to rifting and opening of the South Atlantic Ocean.

\section{Namibe Angolan margin development}

The Namibe Basin, also called the Mossamedes Basin (Giresse et al. 1984), was formed during the Jurassic-Early Cretaceous rifting of the South Atlantic margin. This basin includes the southern edge of the West African Salt Basins (WASB) at the southern end of the Angolan margin. To the south, the basin is limited by the Walvis Ridge, which separates it from the basins of the Namibian margin (Fig. 1).

Fluvial-lacustrine sedimentary rocks typical of an intracratonic environment possibly equivalent to that of the Karoo sedimentary rocks have recently been recognized along the

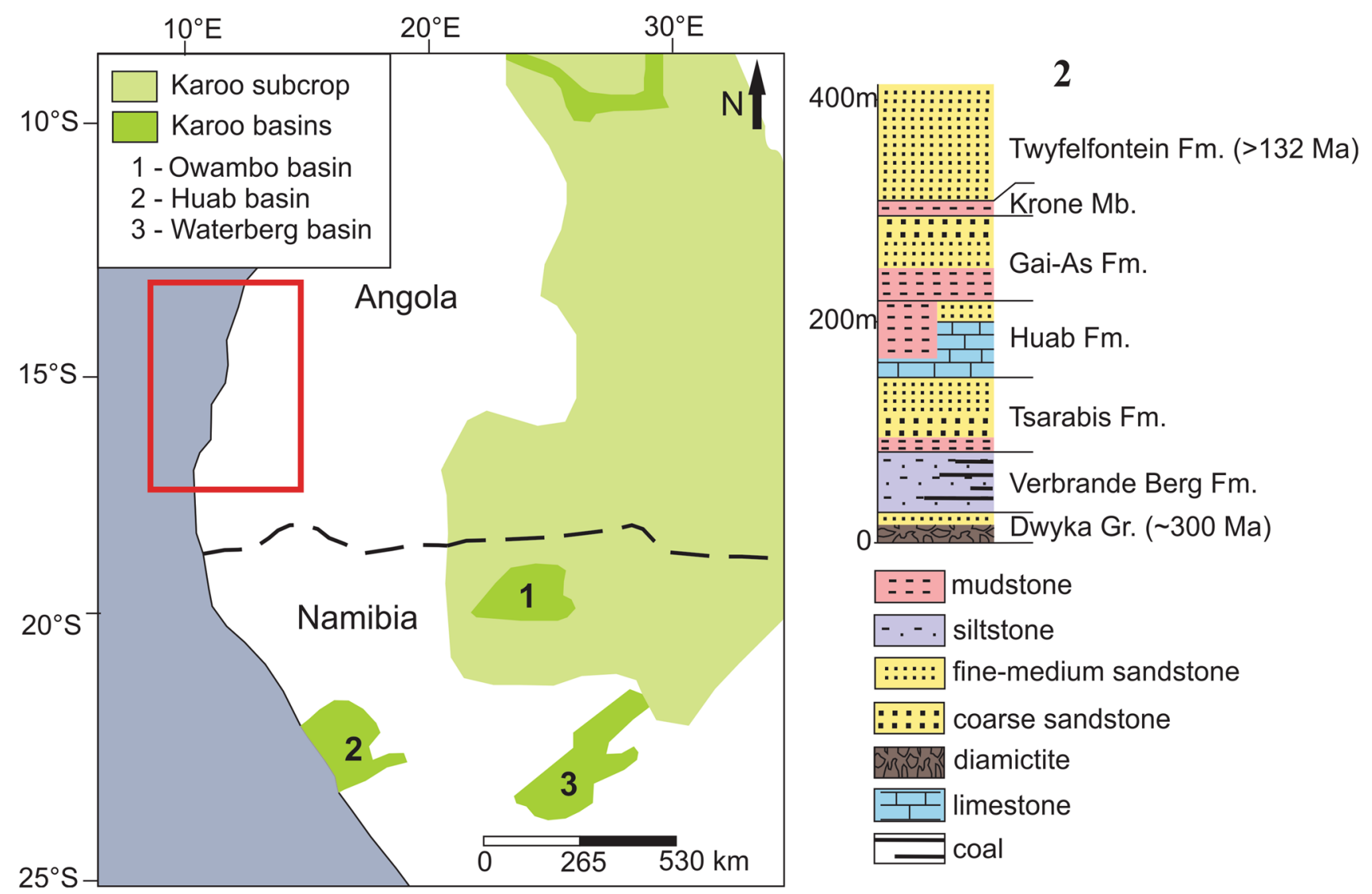

Fig. 2 Distribution of the Karoo sedimentary rocks around the study area (red rectangle), as per Catuneanu et al. (2005). Karoo sedimentary rocks outcrop within the exposed areas of the Owambo, Huab, and Waterberg basins and subcrop to the eastern side of Angola 
onshore Namibe margin (e.g., Beglinger et al. 2012; GindreChanu et al. 2015, 2016), indicating that there was a pre-rift stage (Fig. 3).

During the rifting period, the Namibe Basin was filled by a thick fluvial-lacustrine sequence (Maslanyj et al.
1992; Koch and Coole 2014; Fig. 4) and by a volcanic extrusion at $\sim 130 \mathrm{Ma}$ equivalent to Etendeka volcanics in Namibia, named the Bero Complex (Marsh and Swart 2016), which also overlapped unconformably the pre-rift sequence (Beglinger et al. 2012) (Fig. 3).

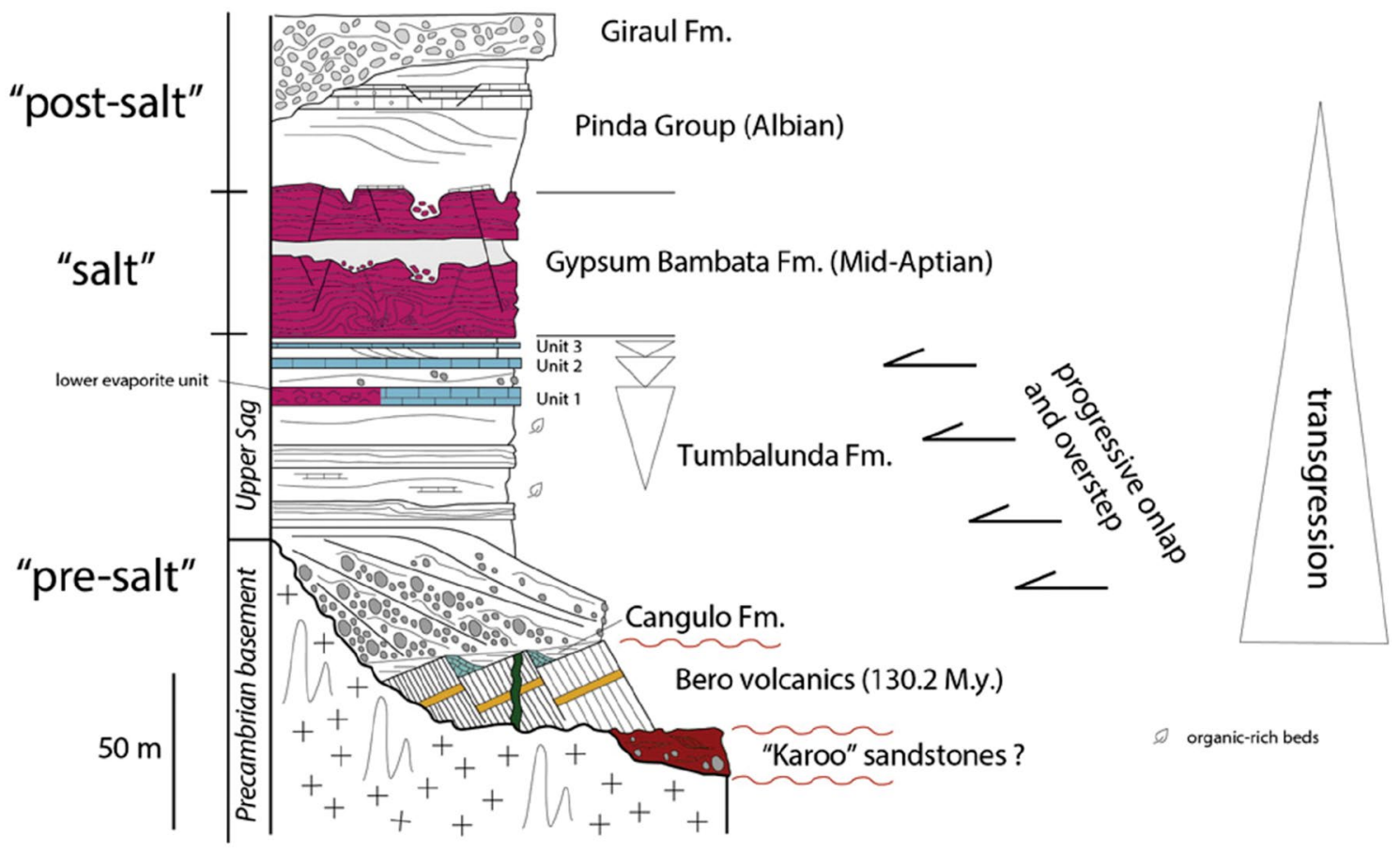

Fig. 3 Schematic stratigraphic section from the onshore Namibe Basin, showing the pre-salt deposits, Bambata Formation (salt), and post-salt deposits, as per Gindre-Chanu et al. (2016)

Fig. 4 Geological section from the offshore Namibe basin interpreted from 2D seismic section and gravity modeling, as per Reid and Ashfield (2016)

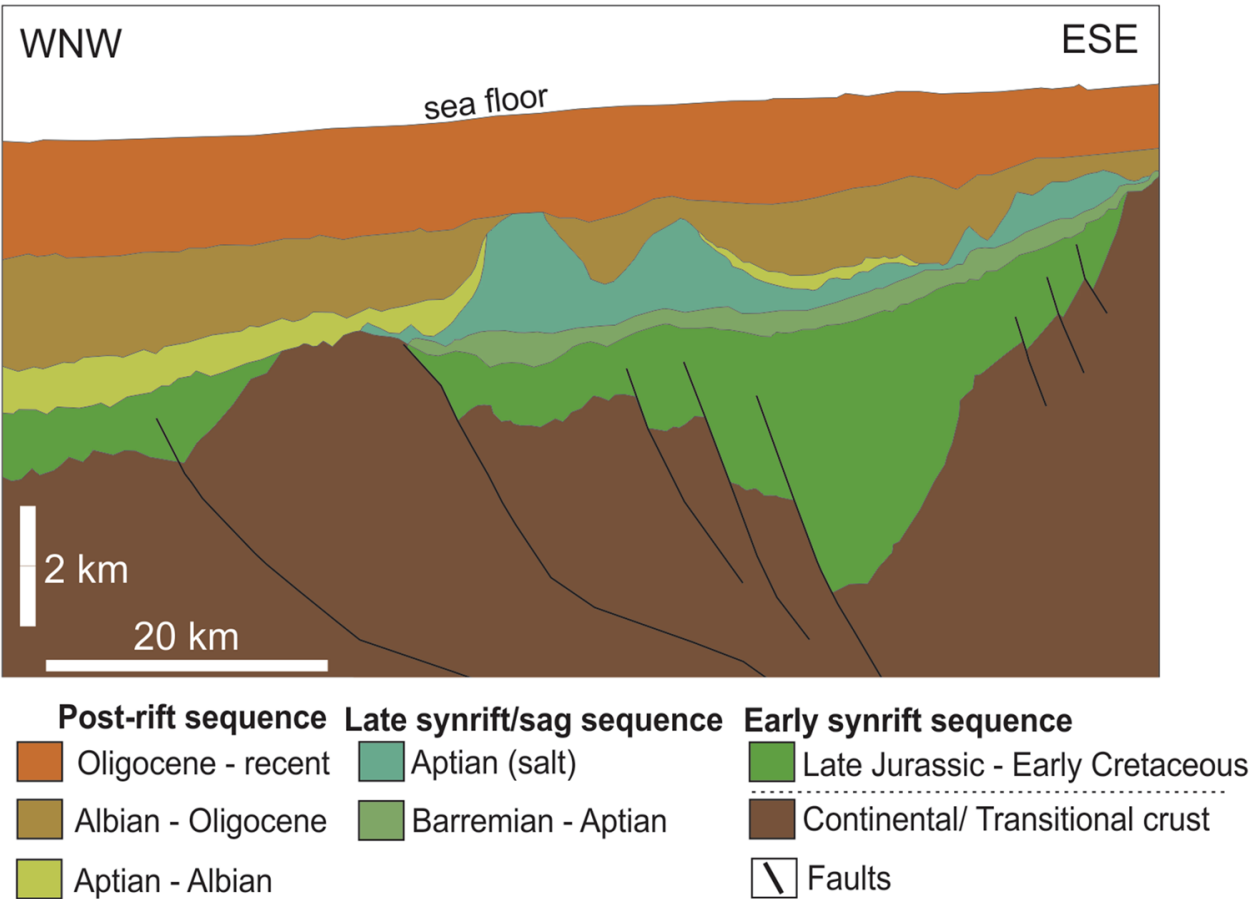


During Late syn-rift, the Bero volcanic was capped unconformably by a transgressional sequence, represented by the Cangulo and Tumbalunda Formations, marking the sag stage of the Basin (Gindre-Chanu et al. 2016, Figs. 3, 4). In the Central South Atlantic, this stage is interpreted as the result of the thermal relaxation of the lithosphere, which may have been associated with the heat flow migration towards the future breakup zone (e.g., Brune et al. 2014). The thermal subsidence of the Namibe margin culminated with the salt deposition and gypsum of the Bambata Formation (Fig. 3), which is part of the widespread lake environment established in the Aptian in Central South Atlantic (e.g., Kukla et al. 2018). The continental breakup north of Walvis ridge occurred at $\sim 112 \mathrm{Ma}$ (Torsvik et al. 2009; Blaich et al. 2011) marking the establishment of the post-rift stage. Over the Bero volcanic rocks, incised valleys filled with Albian conglomerates have also been recognized (Marsh and Swart 2016).

The shallow-water marine sedimentary rocks of the Midto Late Cretaceous Salinas Formation were also deposited, overlying the continental syn-rift deposits (Strganac et al. 2014, Fig. 5). In addition, the gypsum found along the Namibe coast shows diagenetic features indicating that these rocks were heated by burial during post-rift times (GindreChanu et al. 2016).

In the Late Cretaceous, a NW-SE tectonic shortening probable caused by a rotational change between the African and South American plates induced new surface uplift events along the margin and inland region during the Santonian event (Binks and Fairhead 1992; Guiraud and Bosworth 1997). The change in seafloor spreading rates and surface uplifts, were recently attributed to the pulsation of the African plume, and to its southward migration in relation to the African plate (O'Connor et al. 2018). An increase in continental erosion during the Late Cretaceous can be seen in some places along the Namibe margin (Dinis et al. 2010), and is related with the development of a regional erosional surface over both the Pre-Cambrian basement and Bero volcanic extrusions (Green and Machado 2015; Marsh and Swart 2016). Moreover, in the Late Cretaceous, the top of the Salinas Formation was submitted to considerable levels of weathering, and mineral recrystallization due to the overlap of the shallow-water to continental Ombe basalts (Strganac et al. 2014).

Between the Late Cretaceous and Early Cenozoic, the Ombe basalts were capped unconformably by the marine sedimentary rocks of the Baba and Macuio Formations (Strganac et al. 2014, Fig. 5), followed by a set of clastic marine sedimentary rocks (Beglinger et al. 2012). Furthermore, at the eastern edge of the current onshore Namibe Basin, Maastrichtian to Cenozoic sedimentary rocks are recognized over the previously developed Late Cretaceous erosional surface (Green and Machado 2015; Marsh and Swart 2016).
At Oligocene-Miocene, an increase in the sediment supply along the Angolan marginal basins was driven by continental surface or tectonic uplifts (Lavier et al. 2001; Hudec and Jackson 2002; Jackson et al. 2005) evidenced by preserved marine strata at tens and hundreds meters above the present-day sea level (Giresse et al. 1984; Guiraud et al. 2010, Fig. 6), and by the longitudinal convex profiles from the marginal rivers, which demonstrate the relief immaturity (Macgregor 2013; Gröger et al. 2013; Guiraud et al. 2010; Roberts and White 2010). The increased continental erosion along the Angolan margin was also driven by a relatively wet climate, which was probably consequence of a northward continental migration that started at Mid-Cenozoic (Séranne and Anka 2005). In addition, large submarine fans associated with potential hydrocarbon sources in turbidite deposits have been developed since Oligocene-Miocene times along the Angolan margin (e.g., Macgregor 2010; Babonneau et al. 2010).

\section{Previous thermochronological data}

Few thermochronological papers along the Angolan margin have been published. Jackson et al. (2005) and Green and Machado (2015) presented AFT data from within and adjoining basement along the Kwanza and Namibe Basins. They have constrained AFT thermal events by overlapping in time constraints derived from fission-track data solutions, then, the thermal histories were obtained from palaeotemperatures estimates.

Jackson et al. (2005) proposed three regional cooling events in the Kwanza margin for the periods of 150, 100-70, and 20-10 Ma, where the oldest is associated to maximum palaeotemperatures from 135 to $100^{\circ} \mathrm{C}$ and the youngest with palaeotemperatures from 45 to $30^{\circ} \mathrm{C}$. They also have interpreted these events in terms of exhumation and volcanism during rifting ( $150 \mathrm{Ma}$ event), exhumation related to tectonic and volcanism (100-70 Ma event), and exhumation (20-10 Ma event).

Five major cooling onsets affecting the Namibe margin have been proposed by Green and Machado (2015) for the periods of $320-285,195-165,120-112,95-70$, and 35-20 Ma, which were separated by heating episodes. The authors, based on the remnants of sedimentary strata preserved over the basement erosion surface, interpret these events in terms of episodic burial and exhumation.

In summary, Green and Machado (2015) propose a polycyclic evolution for the Namibe margin based on integration between geological evidence and thermal history constraints. For the Kwanza margin, Jackson et al. (2005) interpret their thermal history constraints or estimates of palaeotemperatures as maximum possible values for burial estimates, and consider other possible causes of heating besides burial. 
Fig. 5 Stratigraphic section from the onshore Namibe Basin, showing the Late Cretaceous Formations, as per Strganac et al. (2014)

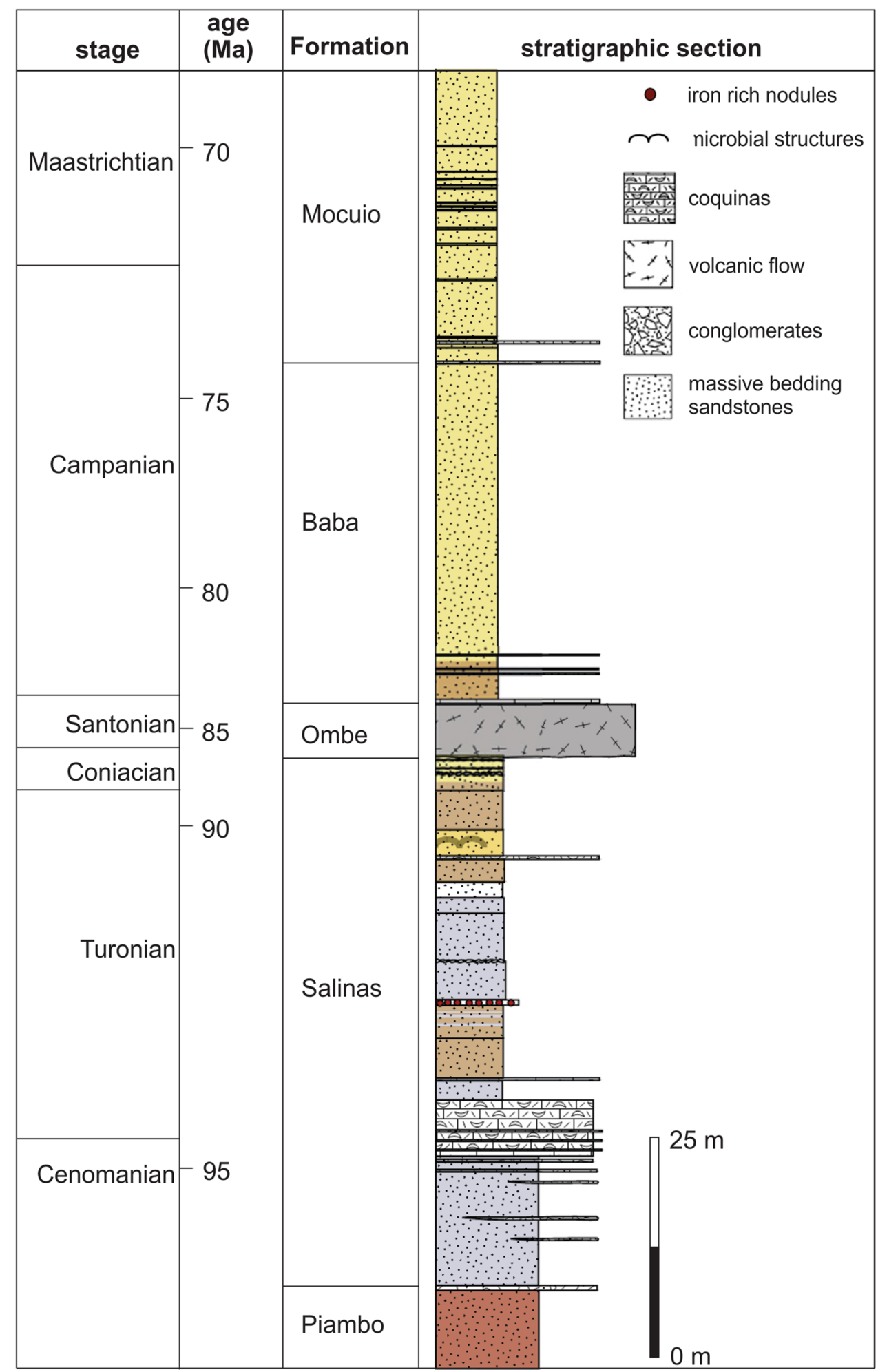


Fig. 6 Palaeo-valleys, palaeoterraces, and elevated cliffs above the current sea level in the Lobito (a) and Cuio (b) regions, Benguela margin, as per Guiraud et al. (2010)

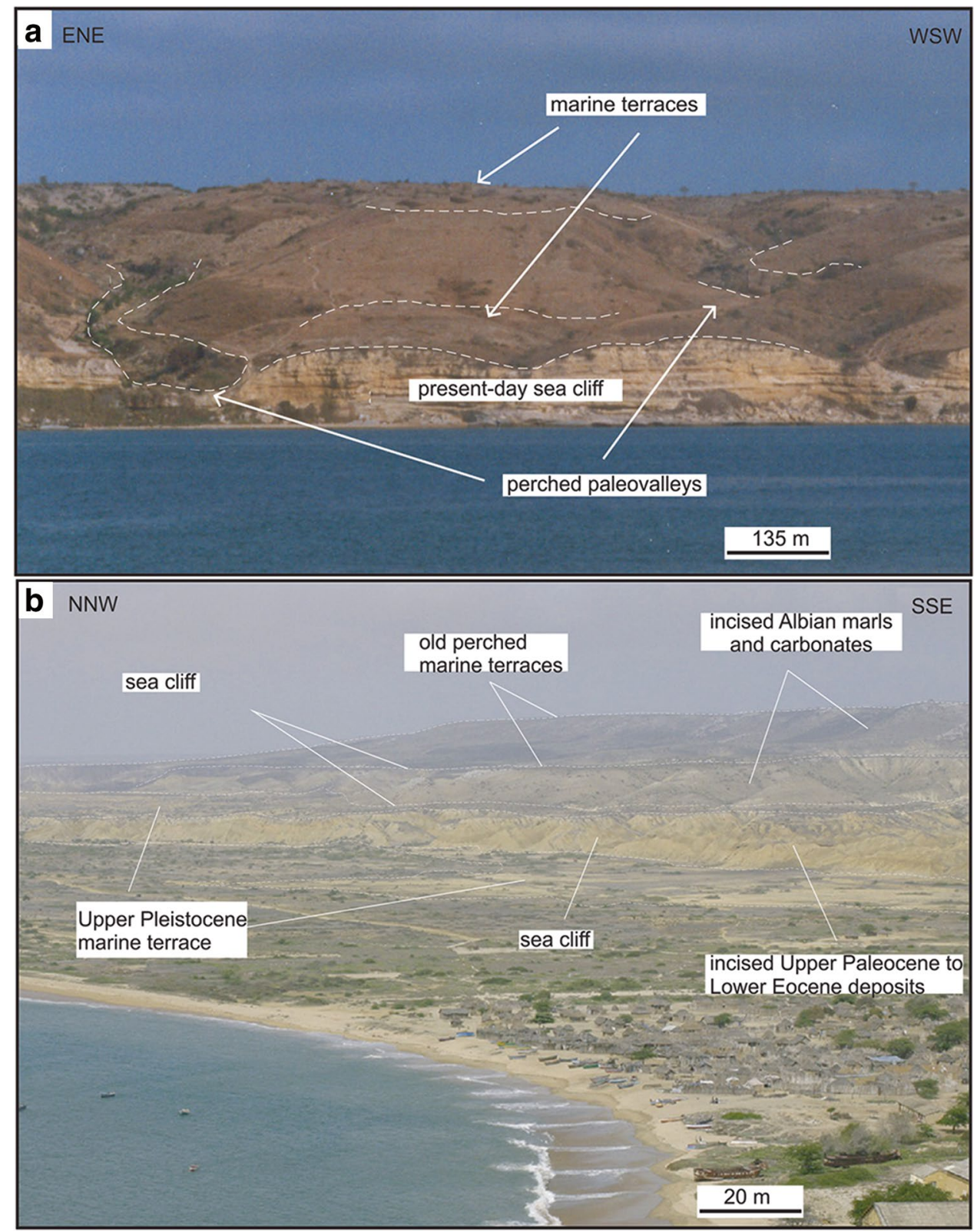

\section{New apatite fission track and (U-Th)/He analysis}

\section{Sampling strategy and methods}

Thermochronological data were obtained from six outcrop samples from the Namibe Angolan margin, ranging in elevation from 57 to $1026 \mathrm{~m}$. The samples were collected in the same E-W transect analyzed by Green and Machado (2015) and extends from the coast toward the base of the Chela Escarpment (Fig. 7). The sampled rocks encompass the Early Cretaceous quartz-latites (Bero Complex) located in the eastern edge of the onshore Namibe Basin, and the
Archean to Palaeoproterozoic basement granites further inland.

First, apatite grains were concentrated by crushing and mineral disaggregation using high voltage pulse power fragmentation (Selfrag) at the Geochronology laboratory at the University of Brasilia, Brazil. Selfrag works with injection of electrical pulses in a sample and the fragmentation occurs at the edge between mineral grains, preserving their shape.

After, samples were separated for apatite using heavy liquid, magnetic separation, and hand picking methods. Apatite grains were mounted in epoxy, polished, and etched in $5.5 \mathrm{M} \mathrm{HNO}_{3}$ for $20 \mathrm{~s}$ at $21{ }^{\circ} \mathrm{C}$ after Donelick et al. (2005). For all samples, the AFT data were analyzed by the external detector method, which allows dating 


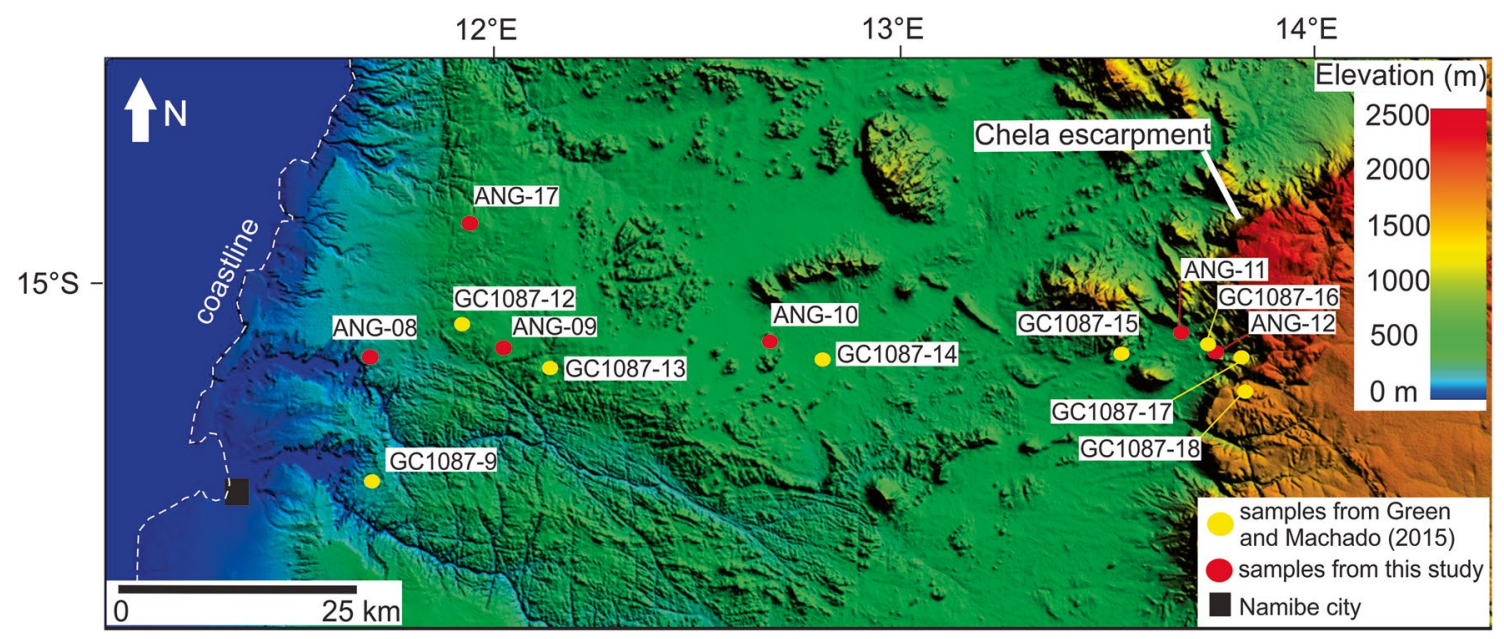

Fig. 7 Topographic map (SRTM image) of the Namibe Angolan margin. The red circles show the sample locations used to constrain the thermal histories of this study

individually the apatite grains from the same sample (see Gallagher et al. 1998; Gleadow 1981). Fission-track counting was performed using an optical microscope Zeiss Axio Imager M1 coupled with an MRc5 camera and Axio Vision software.

For AHe method, single apatite grains from each sample were observed under the Zeiss Discovery V8 microscope at a magnification of 80 and were categorized according to their shape, size, and lack of obvious fractures and U- or Th-rich inclusions. Samples Ang-17, Ang-08, Ang-09, and Ang-10 yielded high-quality apatite grains which were picked, measured for their length and width using Zeiss Imager software, and were then placed inside Pt tubes.

Apatite grains loaded into the Pt tubes were placed in a $\mathrm{Cu}$ planchette and outgassed into a high vacuum by rastering a focused diode laser beam of $960 \mathrm{~nm}$ (Photon Machines). Determinations of ${ }^{4} \mathrm{He}$ were conducted in static mode, with ${ }^{4} \mathrm{He}$ detection performed in a Faraday cup using a split flight tube noble gas mass spectrometer (GVI-HelixSFT). After degassing, isotopic dilution was used by spiking the samples with a known amount of ${ }^{235} \mathrm{U}$ and ${ }^{230} \mathrm{Th}$ and the amounts of ${ }^{238} \mathrm{U}$ and ${ }^{232} \mathrm{Th}$ were measured using a single-collector double-focusing sector field inductively coupled plasma mass spectrometer (SF-ICP-MS, ELEMENT 2).

\section{AFT data}

The central AFT ages range from $120.6 \pm 8.9$ to $272.9 \pm 21.6 \mathrm{Ma}$ and each sample shows single grain age dispersion compatible with a Poissonian distribution (chisquare probability are $>77 \%$, Table 1), suggesting that the grains in each sample belong to the same population (Green 1981, Galbraith 1981). The central AFT ages show an apparent positive correlation with the elevation (Fig. 8). This may be interpreted as older samples have cooled from lower palaeotemperatures when comparing to the younger ones (e.g., Raab et al. 2002) or that those samples may have cooled from the same level, with the samples with older ages having been partially overprinted while those with younger ages were totally overprinted.

The AFT ages from the Bero volcanic samples either overlap with (Ang-08) or are slightly older (Ang-17) than their stratigraphic ages, which could reflect the time of the rock emplacement for the first, and a more complex thermal history for the last. The basement samples yielded AFT ages much younger than their stratigraphic ages (Table 1) supporting that the thermal histories of these samples were driven by Phanerozoic events.

The mean confined track length (MTL), uncorrected to the $\mathrm{c}$-axis angle, varies between $9.6 \pm 0.3$ and $10.8 \pm 0.3 \mu \mathrm{m}$ and are associated to track length distributions (TLD) relatively broader (standard deviations between 1.9 and $2.3 \mu \mathrm{m}$ ). By contrast, the c-axis corrected MTL (all confined tracks were corrected to the c-axis angles according to Ketcham et al. 2007a) varies between $12.3 \pm 0.2$ and $13.0 \pm 0.2 \mu \mathrm{m}$ and are associated to narrower and unimodal TLD (standard deviations between 0.9 and $1.4 \mu \mathrm{m}$ ) (Table 2).

The uncorrected and corrected MTL values are within the range reported by Raab et al. (2002) along the Namibia margin further south, and are within the range reported by Green and Machado (2015) for the Namibe Angolan margin (Fig. 9). However, recent studies point out that c-axis corrected track lengths best represent the annealing conditions of a sample (Ketcham et al. 2015, 2007a) and the corrected track lengths from this study are more compatible with values reported by Green and Machado (2015) for the same area 


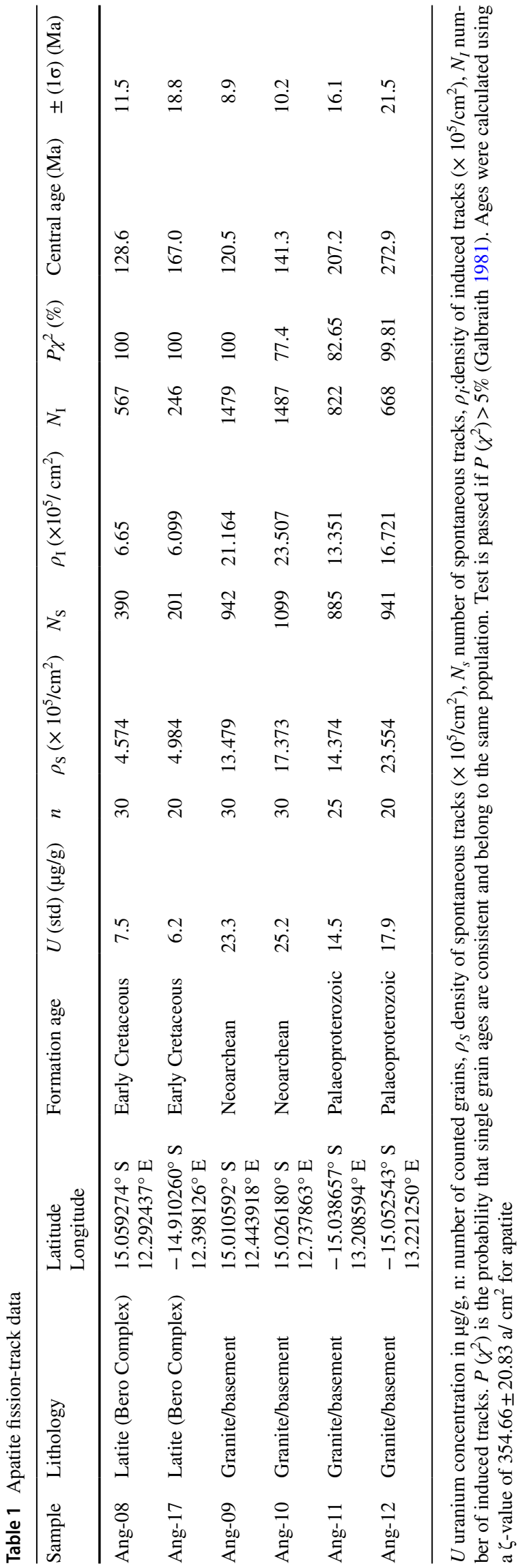

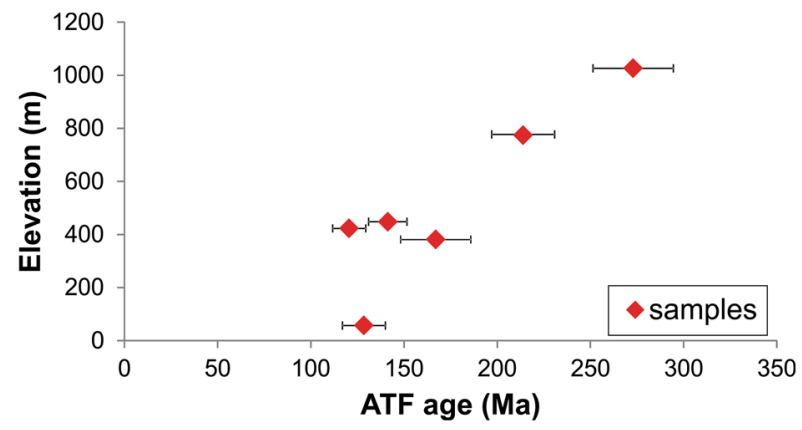

Fig. 8 AFT ages plotted against elevation for samples from this study

(Fig. 9). Therefore, we adopted c-axis corrected lengths for further interpretations.

These corrected MTL values suggest that all samples were subjected to a moderate degree of annealing, implying moderate cooling rates or even more complex thermal histories (e.g., Gallagher and Brown 1997). Even the Early Cretaceous Bero volcanic rocks (samples Ang-17 and Ang-08) show relatively annealed MTL values $(\sim 12.3 \mu \mathrm{m})$, implying that they underwent significantly heating postemplacement and probably, did not remained at surface temperatures during their geological evolution. The Dpar values vary between 1.6 and $1.8 \mu \mathrm{m}$ (Table 2). According to Carlson et al. (1999), Dpar values below and above 1.75 (i.e., apatite etched in $5.5 \mathrm{M} \mathrm{HNO}_{3}$ for $20 \mathrm{~s}$ at $21{ }^{\circ} \mathrm{C}$ ) might suggest more fast-annealing and more slow-annealing apatites, respectively.

\section{AHe data}

The AHe data are summarized in Table 3. Most of the analyzed apatite grains have a spherical equivalent radius $\left(\mathrm{R}^{*}\right)$ around or larger than $60 \mu \mathrm{m}$, which minimize the influence of alpha ejection effect on AHe ages (Farley et al. 1996). The alpha ejection correction $(\mathrm{Ft})$ is appropriated for euhedral apatite grains (two preserved terminations $-2 \mathrm{~T}$ ) assuming a homogeneous distribution of $\mathrm{U}$ and $\mathrm{Th}$ within the grains (Farley et al. 1996; Ehlers and Farley 2003). Considering that most of the analyzed grains are large ( $>60 \mu \mathrm{m}$ radius), preserve one termination (1T), and we did not account for isotopic zoning within the grains, we used uncorrected $\mathrm{AHe}$ ages for interpretations.

The Bero volcanic samples Ang-17 (12 grains) and Ang08 (9 grains) are characterized by low dispersion $(<15 \%)$ of their single grain AHe ages, which vary from $70.0 \pm 1.3$ to $111.2 \pm 3.0 \mathrm{Ma}$ and $66.3 \pm 1.2$ to $104.8 \pm 2.5$, respectively (Table 3). Sample Ang-08 lack a clear age - effective uranium (eU) and age $-\mathrm{R}^{*}$ correlations, while sample Ang-17 lack a clear age $-\mathrm{eU}$ correlation and appear to show a positive age $-\mathrm{R}^{*}$ correlation (Fig. 10). 


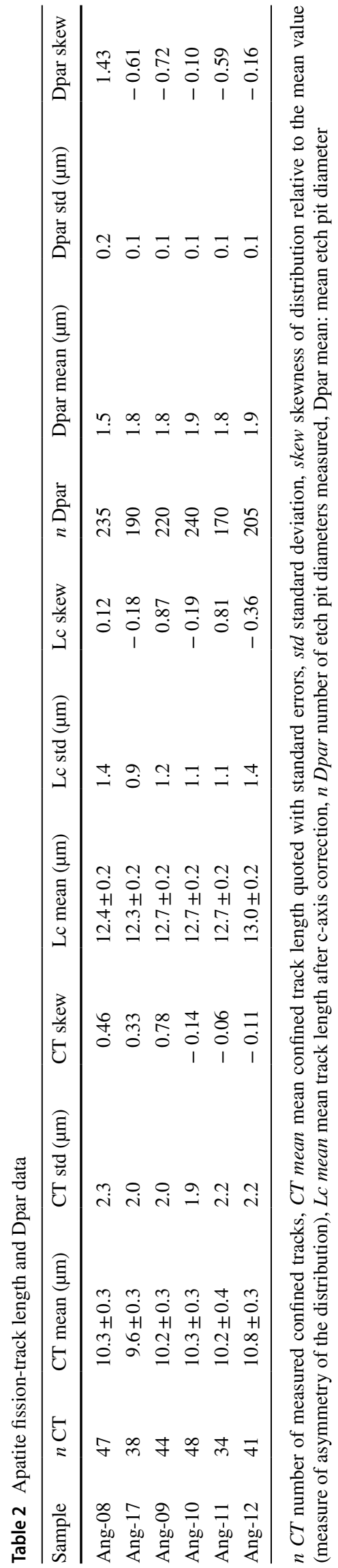

The basement sample Ang-09 (9 grains) is characterized by moderate dispersion of its single grain AHe ages (19.8\%), which vary from $88.7 \pm 0.7$ and $130.2 \pm 1.8 \mathrm{Ma}$ and show an anomalous single age of 177.2 $\pm 1.6 \mathrm{Ma}$. This sample seems to show lightly positive age-eU and age- $R^{*}$ correlations. By contrast, the basement sample Ang-10 (13 grains) yielded single grain AHe ages highly dispersed (30.5\%) varying from $52.2 \pm 1$ to $150.3 \pm 1.2 \mathrm{Ma}$. This sample exhibits a positive age- $R^{*}$ correlation and a negative age-eU correlation (Fig. 10).

In summary, the lack of age-eU correlation combined with the lower inter-grain age dispersion for samples Ang08 and Ang-17, suggest that they underwent relatively fast cooling from higher temperatures, faster cooling rates or shorter residence time within the apatite He partial retention zone (AHePRZ, $~ 40-80^{\circ} \mathrm{C}$ ) in comparison to sample Ang09 , which shows moderate age dispersion and an apparent positive age $-\mathrm{eU}$ and age $-\mathrm{R} *$ correlations. By contrast, the highly dispersed AHe ages without positive correlation with eU for sample Ang-10 suggest the influence of different competing factors on ages, including grain size (e.g., Reiners and Farley 2001), radiation damage (e.g., Flowers et al. 2009; Gautheron et al. 2009), U, Th and Sm zonation (e.g., Flowers and Kelley 2011), crystal chemistry (e.g., Gautheron et al. 2013), crystal fragments (e.g., Brown et al. 2013), He implantation (e.g., Spiegel et al. 2009), and the presence of U- and Th-rich inclusions (e.g., Vermeesch et al. 2007). Bearing this in mind, we are unable to account the contribution of these different factors on AHe ages dispersion, and therefore, we prefer to adopt a more conservative approach and do not use these data to interpret the thermal history of sample Ang-10, as recommended by Flowers and Kelley (2011).

\section{Combining AFT and AHe data}

AFT and AHe ages results from thermal history samples, and they are influenced by the competing factors discussed above. Despite of the ages do not necessarily mean a specific time event, our AFT ages are from Early Cretaceous (with exception of Ang-17) and the single grain AHe ages range from Early to Late Cretaceous suggest cooling event during this time.

The moderately annealed MTL for Early Cretaceous Bero volcanic rocks suggest that those underwent temperatures within the apatite partial annealing zone (APAZ, $60-120^{\circ} \mathrm{C} / 10 \mathrm{Myr}$ ) post their emplacement and require a post-heating cooling event to cool these rocks until nearsurface temperatures. In addition, their AHe data require a relatively fast cooling or short residence time through $\sim 40-75{ }^{\circ} \mathrm{C} / 1$ Myr. This data aspect suggests that the postemplacement heating was high enough to moderately anneal 
Fig. 9 Plot showing MTL against AFT ages for samples from this study and from Green and Machado (2015). The MTL values from this study fit within the range of values reported by Green and Machado (2015) at the same area, suggesting that both studies support a similar thermal history
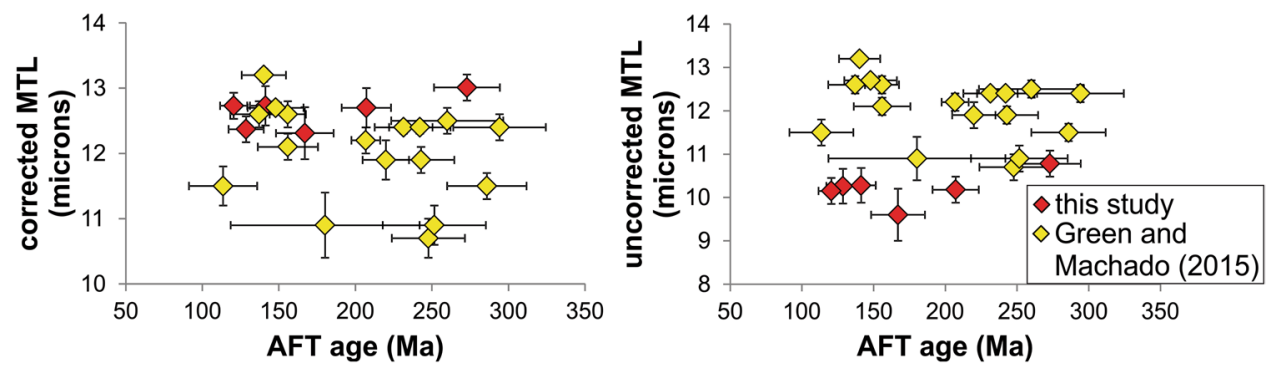

the tracks and to reset the AHe system (above $\sim 75^{\circ} \mathrm{C}$ ); then, the subsequent cooling was relatively fast.

The basement sample Ang-09 shows single grain AHe ages overlapping within or older than its respective central AFT age. This aspect associated to positive eU and $\mathrm{R}^{*}$ correlations with ages support that this sample underwent relatively longer time within $\sim 40-75^{\circ} \mathrm{C}$, a common pattern observed in old cratonic basement rocks (e.g., Flowers et al. 2009; Flowers and Kelley 2011) which were exposed to a long and complex thermal history.

The interpretations above are speculative because temperature ranges of APAZ and AHePRZ vary according differences in apatite compositions and grain sizes (e.g., Reiners and Farley 2001; Flowers et al. 2009; Wildman et al. 2016). Therefore, we provide an inverse modeling to access a better understanding on the thermal history of the southwestern Angolan margin.

\section{Apatite fission track and (U-Th)/He thermal history inversion}

Thermal history models were constrained using the QTQt software, based on a Bayesian transdimensional Markov chain Monte Carlo (MCMC) algorithm. This approach generate acceptable thermal histories within the $95 \%$ confidence limits and are interpreted in terms of the weighted mean of the posterior probability distribution (see Gallagher et al. 2009; Gallagher 2012). In total, we present six inverted thermal histories, three combining AFT and all single grain AHe data (i.e., samples Ang-17, Ang-08, and Ang-09), and three using AFT data (i.e., samples Ang-10, Ang-11, and Ang-12). Samples Ang-11 and Ang-12 did not provide high-quality apatite grains for AHe, while sample Ang-10 presented single grain AHe ages highly dispersed without positive correlation with eU, and therefore, these data were not used to constraint thermal histories as discussed earlier.

AFT modeling was performed with the annealing model of Ketcham et al. (2007b), using Dpar measurements and c-axis corrected confined tracks after Ketcham et al. (2007a). AHe modeling was performed with the RDAAM model of Flowers et al. (2009), which predicts the effects of radiation damage on He retentivity in apatites. For the AFT-AHe modeling, the MCMC algorithm was performed for 200,000 to 300,000 iterations as "post-burn in", after discarding 50,000 iterations as "burn in", while for the AFT modeling, the MCMC was performed for 1,000,000 iterations as "post-burn in" and 200,000 as "burn in" (see Gallagher et al. 2009).

\section{Thermal history constraints and results}

The thermal history models are shown in Fig. 11. For all samples, initial constraints of $130 \pm 5 \mathrm{Ma}, 10 \pm 10{ }^{\circ} \mathrm{C}$ and $70 \pm 10 \mathrm{Ma}, 10 \pm 10^{\circ} \mathrm{C}$ were added on models. The first one is supported by Bero volcanic rocks overlying a basement erosional surface (Marsh and Swart 2016; Gindre-Chanu et al. 2016), indicating that the basement was at near-surface temperatures during the Bero volcanic emplacement. The second one is supported by a Late Cretaceous erosional surface over the Bero volcanic and over the basement, which is covered by Maastrichtian and younger sediments (Green and Machado 2015; Marsh and Swart 2016). This information also supports that the Bero volcanic and the basement were cool prior being buried by those sediments.

For the basement samples Ang-10, Ang-11, and Ang12 which yielded older AFT ages, an additional time constraint of $300 \pm 10$ Ma was included on the models to infer the beginning of the Karoo sedimentation, as supported by correlate sediments recognized onshore (e.g., GindreChanu et al. 2016) and in the hinterland (e.g., Catuneanu et al. 2005). First, the temperature constraint was $30 \pm 30{ }^{\circ} \mathrm{C}$ to consider a range of possible palaeotemperatures for the basement during this time. Second, both time and temperature constraints were adjusted according to the probability increase of the thermal histories. For samples Ang-11 and Ang-12, the thermal histories interval prior $130 \mathrm{Ma}$ were poorly constrained by the AFT data and an additional constraint of $170 \pm 20 \mathrm{Ma} ; 60 \pm 20^{\circ} \mathrm{C}$ was required to increase the relative probability and to better constraint the thermal histories.

Samples Ang-10, Ang-11, and Ang-12 record a period of prolonged heating commencing between Carboniferous-Permian at 300-250 Ma, which reached maximum palaeotemperatures between $\sim 90$ and $50{ }^{\circ} \mathrm{C}$ in the Jurassic times at $\sim 180-170 \mathrm{Ma}$. This heating episode was followed 


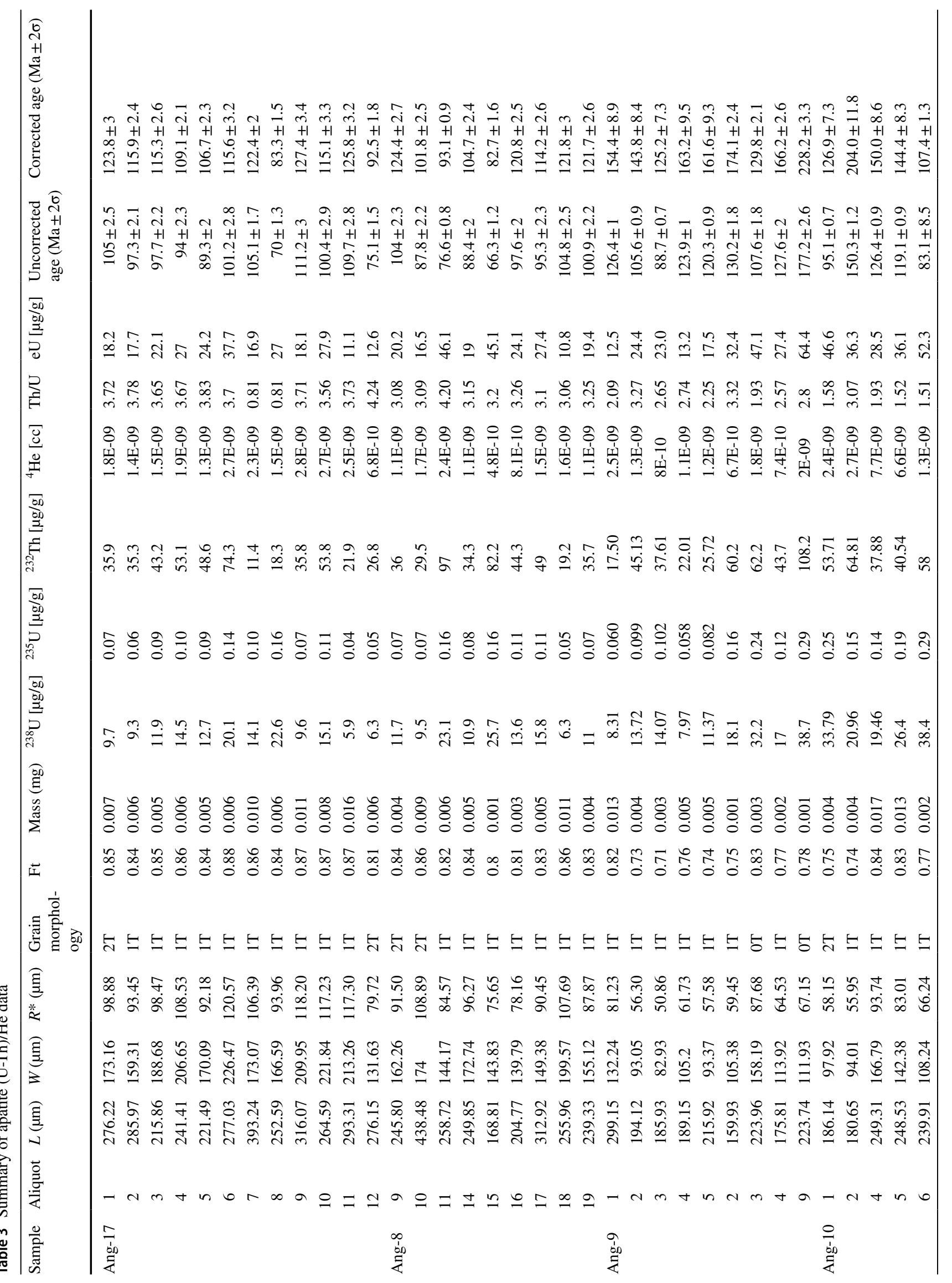


by a strong and abrupt cooling episode from Jurassic at $\sim 180-160$ Ma to Early Cretaceous at $\sim 130 \mathrm{Ma}$ that was recorded in all basement samples.

For samples Ang-08, Ang-10, Ang-11, and Ang-12, the expected models (weighted mean of the posterior distribution) record a period of thermal stability from Early to Late Cretaceous between $\sim 130$ and $70 \mathrm{Ma}$; however, a history involving heating and subsequent cooling during this time interval is also allowed by the models (within the $95 \%$ confidence limits) and thus, it is not precluded by the data. In addition, the sample Ang-17 supports an abrupt heating event commencing at $\sim 130 \mathrm{Ma}$, associated to maximum palaeotemperatures of $\sim 70-60{ }^{\circ} \mathrm{C}$, followed by an abrupt cooling until the surface at $\sim 70 \mathrm{Ma}$. On the other hand, the sample Ang-09 supports a period of thermal stability or gradual slight cooling between $\sim 130$ and $70 \mathrm{Ma}$.

All the analyzed samples record a last prolonged heating event commencing in the Late Cretaceous at $\sim 70 \mathrm{Ma}$, and reaching maximum palaeotemperatures between $\sim 50$ and $20{ }^{\circ} \mathrm{C}$ in the Oligocene-Miocene between $\sim 30$ and $5 \mathrm{Ma}$. This heating requires a last abrupt cooling event to cool those samples until the present-day surface temperatures.

\section{Integration of the thermal events from this study with geology and rifting models}

\section{Early Permian to Early Jurassic heating}

The thermal histories from basement samples support a paleo heating between $\sim 300$ and $250 \mathrm{Ma}$ and 180 and $-170 \mathrm{Ma}$, related to peak temperatures between $\sim 90$ and $50{ }^{\circ} \mathrm{C}$ (Fig. 11). This palaeo-heating event is contemporaneous, and probably, represents the deposition of Karoo sediments over the Namibe basement. This purpose is supported by the occurrence of Karoo outcrops and subcrops on the hinterland (Jerram et al. 1999; Johnson et al. 1996; Miller 1997, Fig. 2) and possibly in the pre-rift sequence from the onshore Namibe Basin (Gindre-Chanu et al. 2015, Fig. 3).

This interpretation is also supported by the similarity of the basement heating presented here with other thermal histories from southern Africa where Karoo sediments outcrop (e.g., Flowers and Schoene 2010; Wildman et al. 2015). In addition, from the AFT data of Brown et al. (2014), it is inferred that Karoo sedimentary rocks could be more extensive and thicker in the geological past than those rocks currently preserved in northern Namibia.

Furthermore, cross-bedded sandstones recognized in the onshore Namibe Basin similar to Karoo were also recognized in the Botucatu Formation within the Palaeozoic Parana Basin in Brazil (e.g., Scherer 2000). All these evidences support the idea of a large-scale intracratonic basin covering a portion of both African and South American continents 

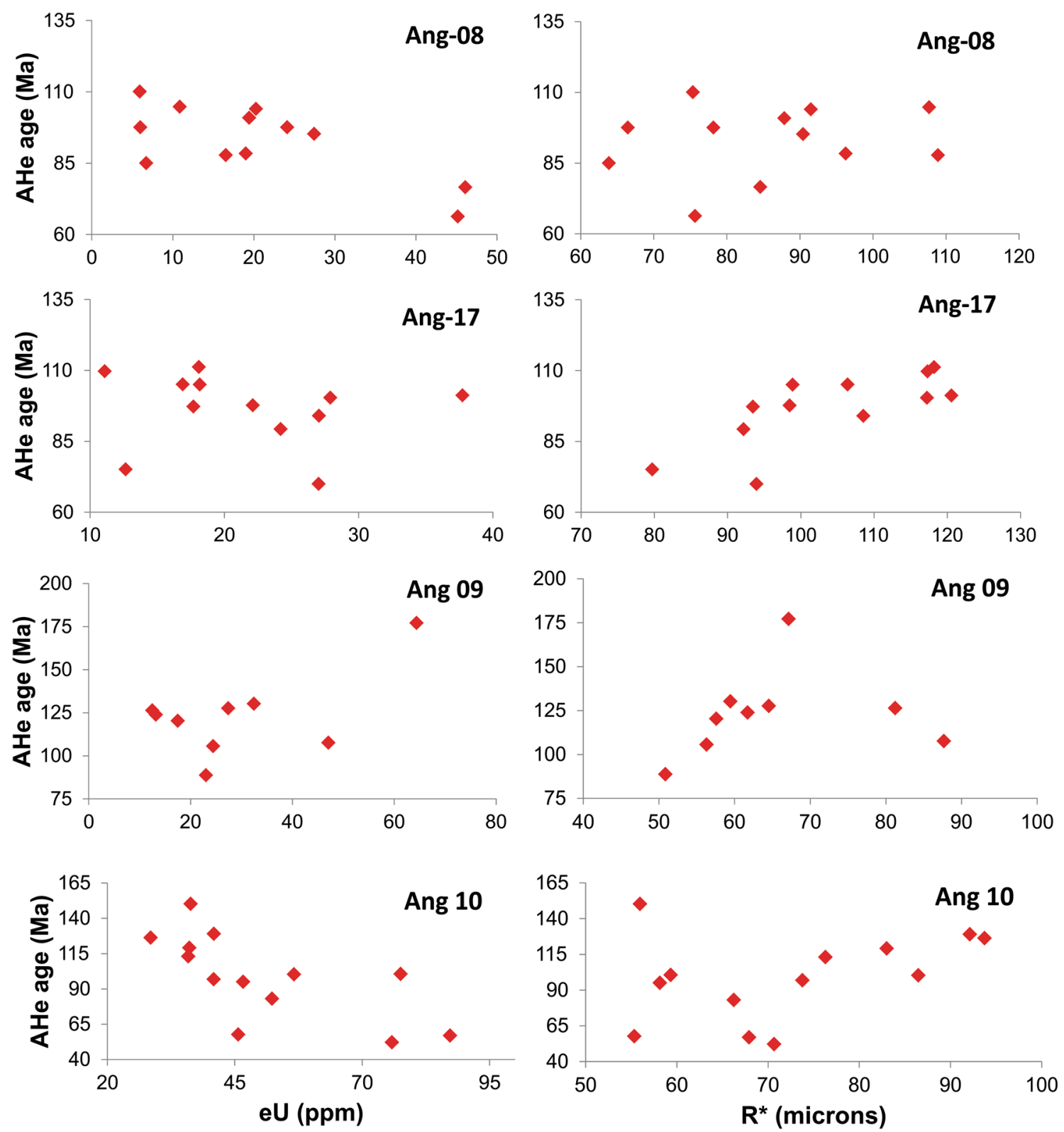

Fig. 10 Relationships of the single grain AHe ages, uncorrected for alpha ejection, against the eU and $R^{*}$ for each sample from this study

prior to the Gondwana breakup, as proposed by Milani and De Wit (2008), among others.

The Jurassic peak temperatures from this study $(\sim 180 \mathrm{Ma})$ also coincide with the extensive Karoo magmatism in southern Africa (Svensen et al. 2012). Considering the relevance of this event in Africa, these Jurassic peak temperatures might be attributed, at least in part, to an additional heat source in complement to burial. For example, Brown et al. (1994) reported peak temperatures of $\sim 250 \pm 50{ }^{\circ} \mathrm{C}$ within the main Karoo Basin, contemporaneous with Karoo magmatism. They suggested that a hydrothermal system related to the igneous activity is an important mechanism able to account for this exceeding heating within the Karoo
Basin, and highlighted the importance of this process on the shallow crust.

\section{Early Jurassic to Early Cretaceous cooling}

The first palaeo-cooling episode recorded by the basement samples encompasses a time interval between $\sim 180$ and $170 \mathrm{Ma}$ and $130 \mathrm{Ma}$ (Fig. 11), coeval with the Late pre-rift and Early syn-rift stages of the Namibe margin development (e.g., Beglinger et al. 2012). This pronounced paleo cooling event, also suggested by the most AFT and AHe ages (Tables 1,3 ), probably reflects an abrupt exhumation 
event of the basement prior to Bero eruption (e.g., Friedrich et al. 2018).

Pre-rift doming and exhumation processes are classically predicted on magma-rich margins where the initiation of rifting would be induced by convective upwelling asthenosphere. However, these processes would be less obvious in magma-poor margins where rifting is triggered by farfield intraplate stresses, and upwelling mantle would have a secondary role (e.g., Bott 1995). On the other hand, recent studies suggest that pre-rift, or Early syn-rift doming and exhumation, both in volcanic and non-volcanic rifts, are not necessarily induced by hot-spot or active mantle plume, but may also be explained as a consequence of lithospheric extension which facilitates the asthenosphere upwelling (Ziegler and Cloetingh 2004; Franke 2013).

Svartman Dias et al. (2016) studying thinning profiles from geodynamic rift models, compatible with highly asymmetric rift systems such as Santos-Namibe segment of the Central South Atlantic, proposes that the lithospheric mantle is much more stretched and thinned than the whole crust beneath rift flanks, triggering uplift of the proximal domain during rifting. In addition, Huismans and Beaumont $(2011,2014)$ propose a counter-flow of depleted, cratonic lithospheric mantle towards the outer region of the margin, which may have occurred during thinning or distal exhumation phases of the rift evolution. These mechanisms could have removed lithospheric mantle, facilitating upwelling of the asthenosphere and hence tectonic and surface uplift in the proximal domain of the Namibe margin.

Considering that the Namibe margin is very close to the southern, magma-rich segment of the South Atlantic, pre-rift doming, and exhumation could be induced, at least in part, by large wavelength deformation related to mantle plume (e.g., Friedrich et al. 2018; Guillocheau et al. 2018). On the other hand, since the conjugated Santos-Namibe segment presents mainly characteristics of magma-poor margin, such as a highly stretched lithosphere domain, a lack of high impedance seaward dipping reflector sequences (SRDs), and a limited magmatism (e.g., Aslanian et al. 2009; Strozyk et al. 2016; Clerc et al. 2018; Kukla et al. 2018), tectonic processes possibly related to the initial stages of extension, may have played a main hole at a pre-rift stage in the area.

These processes already entering the rift stage would also account for tectonic and surface uplift and exhumation of the rift shoulders in the proximal domain, and thus support the pronounced cooling observed in our models. Many other mechanisms such as flexural uplift by isostatic rebound (Weissel and Karner 1989; Van Der Beek et al. 1994; Burov and Cloetingh 1997), lower crustal flow (Burov and Cloetingh 1997; Péron-Pinvidic and Manatschal 2008; Aslanian et al. 2009; Dressel et al. 2016; Brune et al. 2017), and mantle convection or plume-related processes (Buck 1986; Ebinger et al. 1989; Friedrich et al. 2018) may also have played an important role; however, the weight attributed to each of these distinct mechanisms may not be established in this work.

Regardless of the mechanisms, the existence of an unconformity between pre- and syn-rift sequences in the Namibe onshore (Fig. 3) support a pre-rift doming and exhumation (Ziegler and Cloetingh 2004; Franke 2013; Friedrich et al. 2018). Similarly, syn-rift exhumation in the Namibe margin is supported by the pre-sag unconformity at the top of the Bero volcanic (Fig. 3) and by the thick sedimentary wedge, currently preserved offshore as inferred by geophysical data (Maystrenko et al. 2013; Mazur et al. 2016). A similar correlation between pronounced continental cooling and accelerated denudation during South Atlantic rifting is widespread throughout the southwestern margin of Africa (e.g., Brown et al. 1990, 2002; Green et al. 2015; Tinker et al. 2008; Wildman et al. 2016).

\section{Early to Mid-Cretaceous heating}

Sample Ang-17 requires an Early to Mid-Cretaceous palaeoheating between $\sim 130$ and $110 \mathrm{Ma}$ associated to peak temperatures of $\sim 70-60{ }^{\circ} \mathrm{C}$. Although the thermal histories from the other samples from this study do not show this event clearly, they allow a paleo heating event during this time and allow a wide range of peak temperatures between $\sim 10$ and $60{ }^{\circ} \mathrm{C}$, within $95 \%$ credible intervals (with exception of sample Ang-10 that indicate slow monotonic cooling between $\sim 130$ and $70 \mathrm{Ma}$ ) (Fig. 11). As discussed earlier, this episode is also supported by the relatively annealed MTL values from Bero volcanic samples (Table 2) indicating that those were heated after their Early Cretaceous emplacement.

This palaeo-heating (or possible palaeo-heating) is coeval with the widespread subsidence and burial event that marks the Late syn-rift (sag) stage of the marginal Angolan basins, suggesting that both onshore Namibe Basin and surround basement may be subsided and buried by sediments. In Namibe onshore, this phase of subsidence and burial is also supported by the occurrence of transgressional strata onlapping the Bero volcanic and syn-rift rocks (Strganac et al. 2014; Gindre-Chanu et al. 2015, 2016). In addition, the gypsum and evaporites of the onshore Bambata Formation indicate diagenetic features consistent with their postrift burial (Gindre-Chanu et al. 2015, 2016), which is also supported by the preserved marine strata overlying these evaporites onshore (Green and Machado 2015).

Despite conspicuous geological evidence for subsidence and burial in Namibe onshore, a lack of geological markers limits more interpretations regarding its influence on the basement inland. However, along the eastern edge of the onshore Namibe Basin, Marsh and Swart (2016) described relevant geological aspects: (1) Bero volcanic rocks overlie pre-rift sediments and also the basement; (2) Bero volcanic 

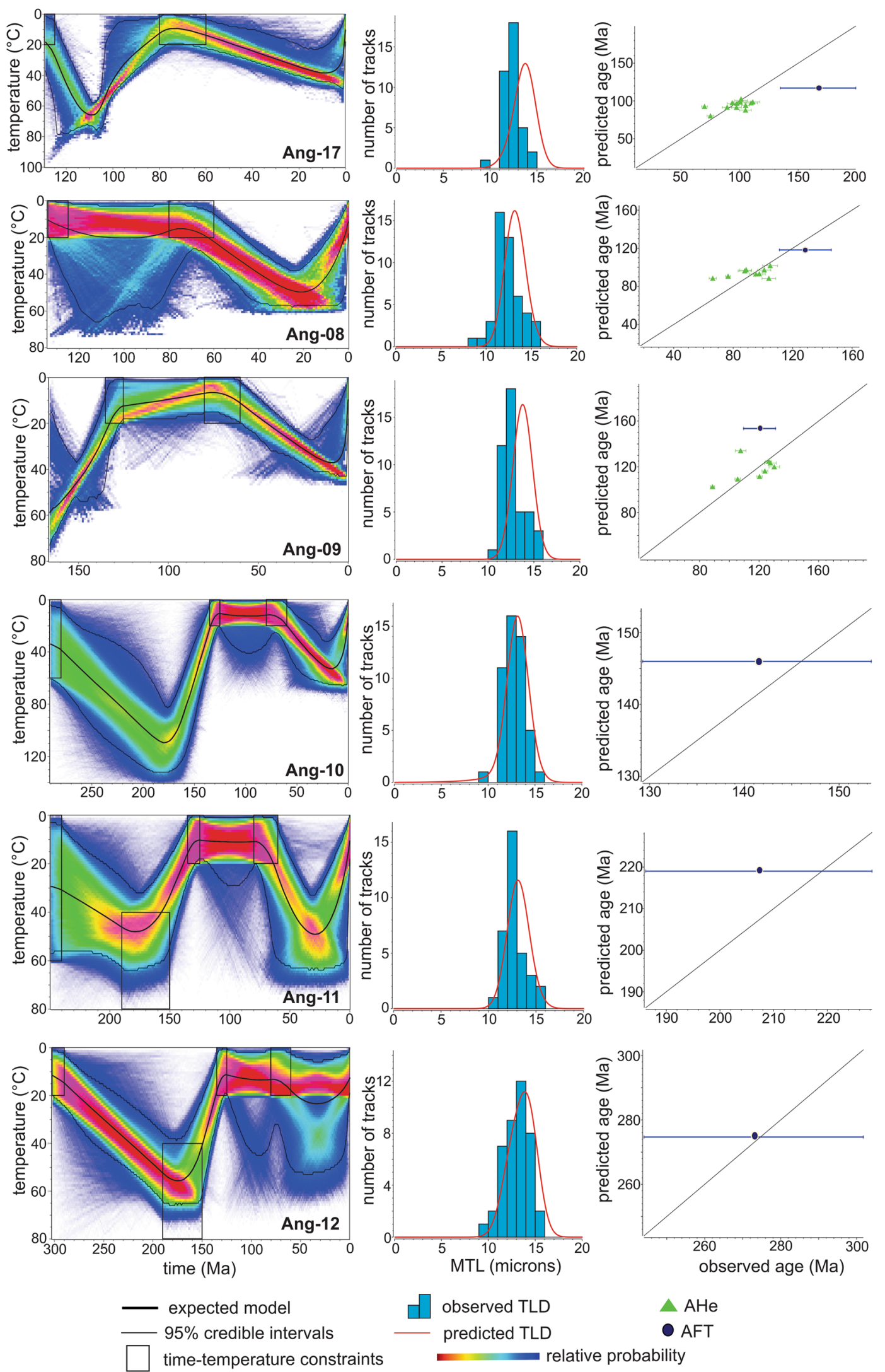
4Fig. 11 Inverted AFT-AHe and AFT thermal histories from this study. In the left hand side are plotted the time-temperature paths: central solid lines indicate the expected model (weighted mean of the posterior distribution) between two other peripheral black lines indicating 95\% credible intervals for the expected models. Colour maps indicate the probability distribution of tested models and the black boxes indicate the constraints on time-temperature. In the right hand side are plotted the AFT and AHe parameters: histograms indicate the observed TLD, red lines indicate the predicted TLD, and the observed AHe and AFT ages are plotted against predicted ages

are usually down-faulted against basement to the west, and Cretaceous sediments are down-faulted against the Bero volcanic to the west; and (3) mafic dykes and gabbroic sheets are found intruding the Bero complex. All those aspects provide evidence for the presence of volcanic and sedimentary rocks in the geological past, covering the present-day proximal domain of the Namibe margin. In other words, the burial of the Bero volcanic by a transgressional sequence reflects the subsidence and burial of the margin by sediments that could be extended further inland.

Bearing in mind that Bero volcanic and basement were subsided and buried post $\sim 130 \mathrm{Ma}$, this burial event requires a following exhumation event of the same magnitude to expose these rocks at the surface temperatures at $\sim 70 \mathrm{Ma}$ (Fig. 11). Therefore, some important aspects regarding the magnitude of this burial could explain the pattern observed on thermal histories. In the Namibe offshore, the Late Cretaceous sedimentary strata is relatively thin, $<1 \mathrm{~km}$ (Maystrenko et al. 2013) suggesting limited Late Cretaceous exhumation event and thus, limited preceding burial. This agrees well with the preserved sedimentary section above the Bero volcanic and below the Late Cretaceous planation surface $(<500 \mathrm{~m})$, suggesting limited burial (e.g., GindreChanu et al. 2016; Strganac et al. 2014). If we speculate conservative burial values between 0.5 and $1 \mathrm{~km}$ for this period, using a geothermal gradient of $25^{\circ} \mathrm{C} / \mathrm{km}$ (Green and Machado 2015), the heating predicted by our thermal histories would be between $\sim 12.5$ and $25^{\circ} \mathrm{C}$, and if we adopt an increased geothermal gradient of $40^{\circ} \mathrm{C} / \mathrm{km}$, the heating predicted would be between $\sim 20$ and $40{ }^{\circ} \mathrm{C}$. These suggest that other sources for heating besides burial may contributed to the peak temperature recorded in sample Ang-17, and thus, the "plateau" indicated by the expect models in other samples (between 130 and $70 \mathrm{Ma}$ ) may be indicative of a minor burial episode (of the order of hundreds of meters) followed by a minor Late Cretaceous exhumation event of similar magnitude.

Evidence from continental subsidence and burial are also reported in the submerged Walvis Ridge, south of the study area (Fig. 1). This ridge probably began to subside in the Albian times and preserve denudation features such as palaeo-incised valleys (Behrmann et al. 2011) suggesting that at least, part of this ridge was at the surface in the past. Furthermore, the occurrence of Etendeka basalts and correlated sedimentary rocks preserved in Namibia hinterland, amongst their AFT data indicating reheating of these units (e.g., Green et al. 2009; Menges et al. 2013) suggests a largescale, continental subsidence episode over the southwestern margin of Africa.

Some rifting models for the South Atlantic (e.g., Brune et al. 2014; Huismans and Beaumont 2014) do not predict subsidence of the proximal domain during the sag stage. However, this paleo heating episode suggests that the subsidence and burial that affected the Namibe Basin (stretched lithosphere and necking domain) could be extended further inland on the basement (proximal domain), and probably, this widespread subsidence and burial event was triggered by a common mechanism.

This interpretation is supported by Svartman Dias et al. (2016) which proposed a model with a lithospheric mantle thinner than the crust beneath the proximal domain. In this case, the subsidence of the proximal domain could be larger and predicted when the rift-related asthenospheric thermal anomaly migrates towards the future breakup zone. Entering the post-rift stage, the subsidence is marked by lithospheric cooling and consequent sediment overburden (e.g., Rowan 2014; Dressel et al. 2017).

Another possible scenario, for example, involves dynamically induced subsidence episodes affecting the southwestern margin of Africa (including the Walvis Ridge region) between $\sim 100$ and $70 \mathrm{Ma}$ (O'Connor et al. 2018). The authors attribute uplift and subsidence events as well as changes in seafloor spreading rates and tectonic reactivations during this time, as consequence of distinct pulses and motions of the African plume.

In summary, the subsidence of the proximal Namibe margin, speculatively, may be interpreted as part of the rift evolutionary process advancing to the post-rift stage in a context in which deep-dependent processes (e.g., Huismans and Beaumont 2011; Svartman Dias et al. 2016) probably affected a broad region beyond the present-day boundaries of the Namibe Basin, instead, deep mantle processes may be directly or indirectly related to subsidence during postrift times (e.g., O'Connor et al. 2018). In addition, specific mechanisms working beneath the proximal domain, such as asthenospheric underplating (Ziegler and Cloetingh 2004; Huismans and Beaumont 2011), removal of the lower crust for core complexes formation (Aslanian et al. 2009; Huismans and Beaumont 2014) may have contributed for subsidence during sag and post-rift phases.

\section{Mid- to Late Cretaceous cooling}

A Mid- to Late Cretaceous cooling event between $\sim 110$ and 100 and $70 \mathrm{Ma}$, following the preceding Early to 
Mid-Cretaceous heating, is required based on the joint interpretation between thermal histories and geological information. This cooling event may be resulted from exhumation, despite other sources of heating that could have contributed for preceding palaeotemperatures. The fact that this event does not appear clearly in most of our models is in partial agreement with AFT data from Green and Machado (2015) which do not support Late Cretaceous cooling in most of their samples alongside the Namibe coast. Instead, the authors identified Late Cretaceous cooling in basement samples around to the Chela escarpment, and a similar cooling event at this location is allowed, but is not required, by our thermal solutions (within $95 \%$ credible intervals) (Fig. 11).

Nevertheless, we list some conspicuous geological aspects: (1) a Late Cretaceous erosional surface is recognized over the basement and Bero volcanic (Green and Machado 2015; Marsh and Swart 2016); (2) the top of marine Salinas Formation was exposed to surface and weathering prior to being covered by Late Cretaceous Ombe basalts (Strganac et al. 2014); and (3) Dinis et al. (2010) describe a Campanian Gilbert delta composed mostly of basaltic and quartzite clasts, indicating local continental progradation. These are relevant arguments for the existence of a Late Cretaceous exhumation event in at least some places along the Namibe margin. Casciello et al. (2016) also recognized a NE-SW faulting trend that probably controlled the emplacement of the Ombe basalts (Bentiaba basanite event), also suggesting that uplifts on the period could be related to tectonic and magmatic events.

Considering that the thermal data have its limitations and the Bayesian approach naturally prefers simpler thermal histories that best fit the data (Gallagher 2012), we propose that there was a minor Late Cretaceous uplift event in the proximal domain of the Namibe margin, which due to its magnitude in comparison to other events, does not appear clearly in our thermal histories. This interpretation is also supported by the thinner Late Cretaceous sedimentary strata currently preserved in the offshore Namibe Basin (e.g., Maslanyj et al. 1992; Maystrenko et al. 2013).

This event consists of a disturbance in the thermal relaxation and subsidence of the lithosphere in the Namibe segment that might be consequence of tectonic stresses, changes in plate spreading rates, dynamic uplift, or a combination of those (e.g., Guiraud and Bosworth 1997; Colli et al. 2014; Friedrich et al. 2018; O’Connor et al. 2018).

\section{Late Cretaceous to Oligocene-Miocene heating}

Thermal histories solutions indicate a last palaeo-heating event beginning at $\sim 70 \mathrm{Ma}$ (Fig. 11). Most samples from this study require Oligocene-Miocene peak temperatures higher than those allowed for Mid-Cretaceous peak temperatures, except for sample Ang-17 (Fig. 11). This data aspect, coupled with geological information indicating minor Early to Mid-Cretaceous burial, support that the major post-rift burial event affecting the proximal domain of the Namibe margin commenced at $\sim 70 \mathrm{Ma}$. Therefore, Oligocene-Miocene peak temperatures of $\sim 20-50{ }^{\circ} \mathrm{C}$ are consistent with a maximum burial estimate between $\sim 0.8$ and $2 \mathrm{~km}$ of sediments, assuming a geothermal gradient of $25^{\circ} \mathrm{C} / \mathrm{km}$ as reported by Green and Machado (2015) for the Namibe margin.

The main geological evidence supporting a new phase of subsidence and burial onshore is the presence of Maastrichtian and young sediments overlying the Late Cretaceous erosional surface (Green and Machado 2015; Marsh and Swart 2016). Another relevant argument is the fact that the marine Baba and Mocuio Formations cover the continental to shallow-water Ombe basalts (Fig. 5, Strganac et al. 2014). We interpret this paleo heating event beginning at $\sim 70 \mathrm{Ma}$ (Fig. 11) as the resumption of the post-rift subsidence and burial of the proximal domain due to the thermal relaxation of the lithosphere.

\section{Oligocene-Miocene to recent cooling}

All samples from this study recorded a last palaeo-cooling episode commencing between Oligocene-Miocene times at $\sim 30-5 \mathrm{Ma}$ (Fig. 11) which is coeval to widespread episodes of continental uplifts, denudation, and increased sedimentation rates within the marginal Angolan basins (Giresse et al. 1984; Jackson et al. 2005; Guiraud et al. 2010; Macgregor 2013).

The smaller magnitude of the Oligocene-Miocene cooling in comparison to the Late Jurassic cooling (Fig. 11), combined with the lack of Cenozoic AFT and AHe ages (Tables 1,3), suggests that exhumation may have been higher during pre- and syn-rift stages of the margin development than those in the Cenozoic times.

Tectonic driven denudation is suggested mainly by the reactivation of faulting activity during the Cenozoic (Casciello et al. 2016). Similarly, the preserved Cenozoic marine strata uplifted up to hundreds of meters above the current sea level (e.g., Giresse et al. 1984; Green and Machado 2015, Fig. 6) could attest for tectonic or epeirogenic processes affecting the Namibe margin.

The observed verticality of the Miocene cooling (Fig. 11) indicates a fast and abrupt exhumation episode with maximum rates of $\sim 0.3 \mathrm{~km} / \mathrm{Ma}$ (assuming a geothermal gradient of $25^{\circ} \mathrm{C} / \mathrm{km}$ and a cooling magnitude of $40{ }^{\circ} \mathrm{C}$ for the last $5 \mathrm{Ma}$ ). This value corroborates with increased uplift rates estimated along the Angolan margin and hinterland for the last $\sim 10 \mathrm{Ma}$, ascribed to mantle convective processes and to the growth of the Bié Dome (Roberts and White 2010). In 
addition, Walker et al. (2016) also proposed that Late Quaternary uplifts along the Angolan margin are consequence of mantle processes, such as convective upwelling. This information is consistent with the appearance of broad swells in southern Africa since $\sim 15 \mathrm{Ma}$ as the result of mantle thermal anomalies (Colli et al. 2018) and corroborates with a growing number of studies suggesting that the modern topography of southern Africa have been formed by uplifts and exhumations events post $\sim 30 \mathrm{Ma}$, which are dynamically supported (e.g., Nyblade and Robinson 1994; Burke 1996; Lithgow-Bertelloni and Silver 1998; Al-hajri et al. 2009; Guillocheau et al. 2018).

Most works along the Namibian and South African margins estimates lower continental denudation rates during Cenozoic (e.g., Brown et al. 1990; Raab et al. 2002; Tinker et al. 2008; Wildman et al. 2015), in comparison to the rates estimated for the Angolan margin (e.g., Lavier et al. 2001; Macgregor 2010). These lower denudation rates in Namibia is supported by thinner sedimentary strata currently preserved offshore (e.g., Maslanyj et al. 1992; De Vera et al. 2010). The details of this process are open to discussion: (1) the differential continental denudation was driven by differential tectonic or epeirogeny between these margins or (2) the differential denudation was driven mainly by climatic changes, whereas the Angolan side has had a relatively wetter climatic conditions since the Oligocene (e.g., Macgregor 2013; Scotese 2000, Serrane and Anka 2005).

Considering that Cenozoic uplifts and vertical displacements have also been reported in Namibia (e.g., Roberts and White 2010; Mvondo et al. 2011; Stollhofen et al. 2014), we propose that the climate has played a fundamental role in the pattern of continental erosion along the Namibe Angolan margin, together with possible tectonic or epeirogenic control.

In conclusion, we propose that the Oligocene-Miocene to recent cooling inferred by our thermal histories (Fig. 11) represents the combination between uplift and erosion driven by tectonic or epeirogenic process, and by relatively wet climatic conditions. This event would also be responsible for the exhumation and exposure of the present-day onshore Namibe Basin and its surrounding basement further inland. This interpretation is in agreement with Jackson et al. (2005), namely that the Kwanza Basin further north (Fig. 1) remained in marine conditions until a last exhumation episode during Miocene - Pliocene times, which was responsible for removing $\sim 1-1.5 \mathrm{~km}$ of overburden from the basement as inferred by AFT data. This information suggests that both basins evolved similarly from a regional uplift episode affecting a large area of the crust, possibly controlled by a common mechanism.

\section{The vertical crustal movements of the namibe Angolan margin and their stratigraphic response}

We restore the main vertical crustal movements that took place along the Namibe Angolan margin during the late half of Phanerozoic by integrating our review with new AFT and AHe data.

In the Carboniferous-Permian times, i.e., at approximately 300-250 Ma, Karoo sediments begin to be deposited in over the Congo Craton, covering the Namibe region (Fig. 12a). In the Jurassic, at approximately 180-170 Ma, the Karoo burial was interrupted by pre-rift doming and exhumation, probably related to the early stages of lithospheric thinning, forming the unconformity between pre- and synrift sequences, currently recognized onshore (Fig. 12b).

During rifting progress, the thinning of the lithospheric mantle beneath the rift flanks (proximal domain) probably caused tectonic and surface uplift, magmatism (Bero volcanic extrusion) and denudation, responsible for transporting large amounts of sediments into the Namibe Basin. The development of down-faulted blocks during rifting probably preserved the Karoo rocks currently recognized in the Basin, and the uplifted blocks above the base-level were partially eroded forming the pre-sag unconformity associated with the formation of incised valleys over Bero volcanic (Fig. 12b). At approximately $130 \mathrm{Ma}$, the heat flow migration towards the outer margin and the thermal relaxation of the lithosphere probably resulted in subsidence and burial, marking the Late syn-rift (sag) stage. The proximal domain was buried by a transgressional sequence that also overlaid the Bero volcanic rocks. The transgression culminated with the salt deposition followed by a set of marine sedimentary strata during the post-rift stage (Fig. 12c).

In the Mid- to Late Cretaceous, between approximately 110 and $70 \mathrm{Ma}$, a disturbance in the thermal relaxation induced reactivation of faults, magmatism (Ombe basalts) and uplift in the Namibe margin. This event is associated to the formation of a conspicuous erosional surface affecting the basement and is related to a local increase of continental erosion (Fig. 12d).

The resumption of the thermal relaxation induced reburial of the margin by Maastrichtian and Cenozoic sediments (Fig. 12e). In the Oligocene-Miocene, at approximately 30-5 Ma, the subsidence and burial of the margin were interrupted by a new abrupt exhumation event, which has been related with faulting and uplifts. In combination with a relatively wet climate, the exhumation along the Namibe margin is increased and this led to an important increase in the siliciclastic flux towards the Namibe Basin. This event was responsible for removing Cenozoic rocks from the present-day proximal domain of the margin, and for the 
a

$\checkmark>300 \mathrm{Ma}$

b $\mathrm{\uparrow}>180 \mathrm{Ma}$
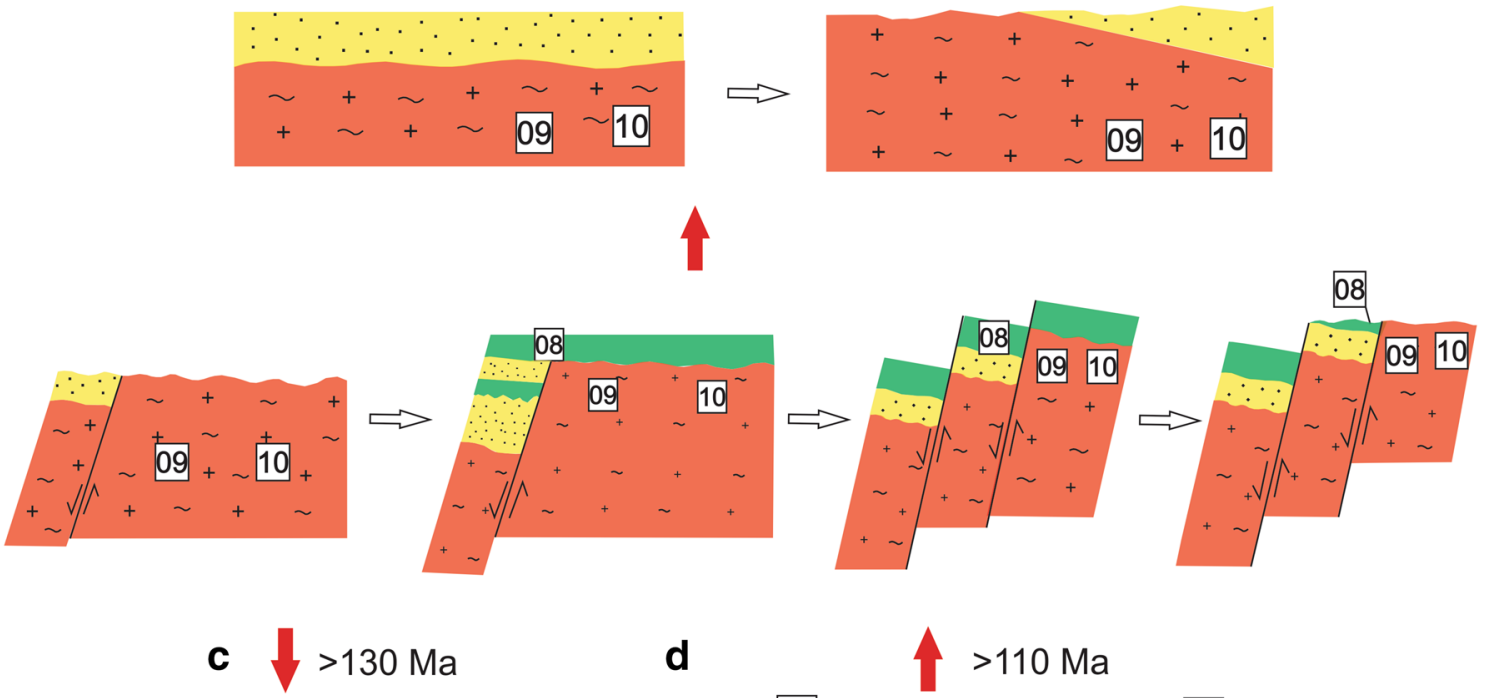

d $>110 \mathrm{Ma}$
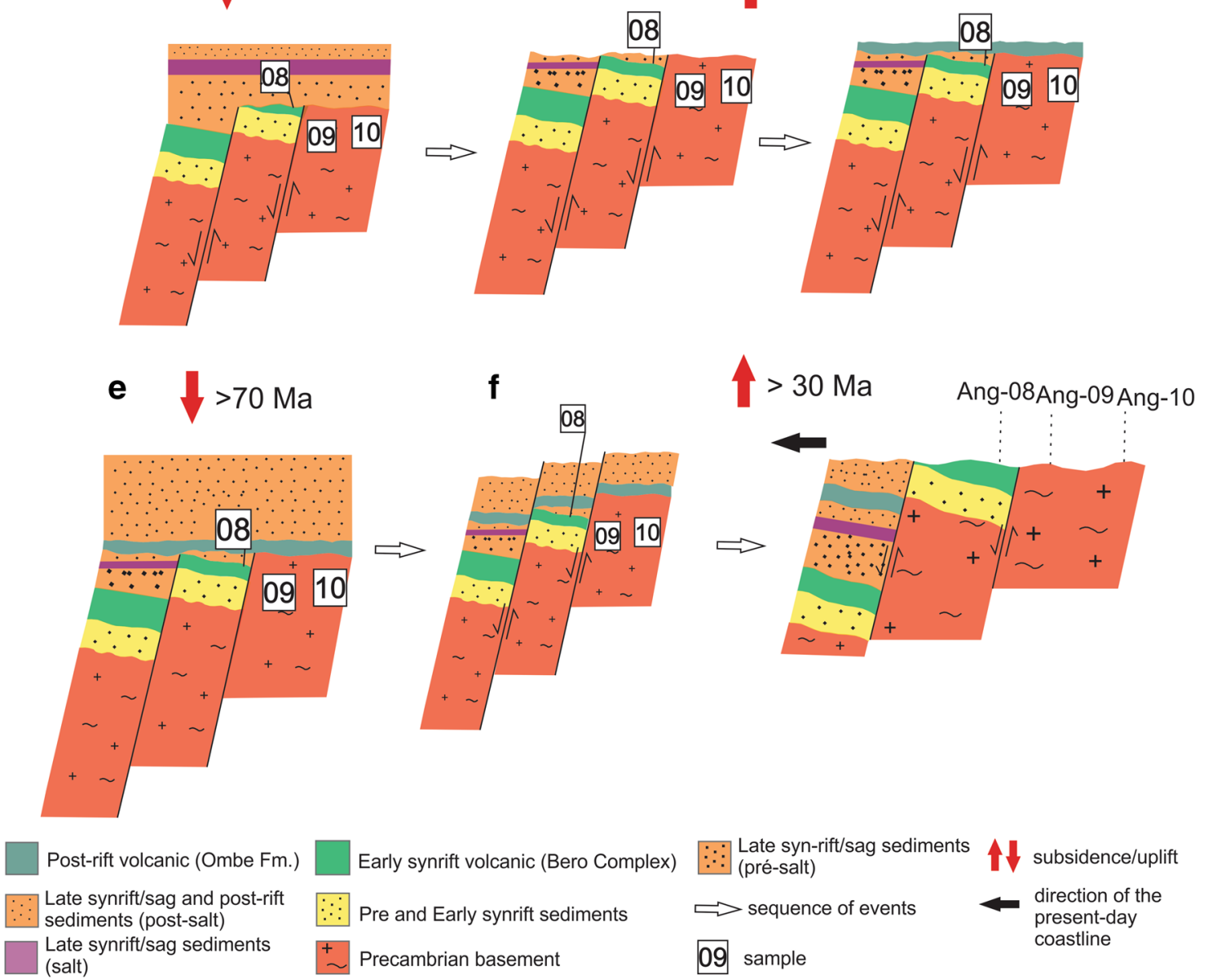

Fig. 12 Schematic development for the Namibe Angolan margin based on integration between geological information and AFT-AHe thermal solutions from this study 
exhumation of the onshore Namibe Basin to its current position. (Fig. 12f).

Despite some differences regarding the magnitudes of the events, the cooling events predicted by our inverted thermal histories are most consistent with the cooling events reported by Green and Machado (2015); hence, our restoration agrees with the model of cyclic episodes of burial and exhumation previously advocated by Green and Machado (2015) for the Namibe margin. Furthermore, our model shows similarities with other polycyclic models worldwide (e.g., Japsen et al. 2006; Green et al. 2015). Recently, Green et al. (2018) have pointed out relevant geological and thermochronological evidence that passive margins worldwide have undergone episodic burial and exhumation events rather than monotonic denudation since rifting. These interpretations are strongly in concordance with our overview presented for the southwestern Angolan margin.

\section{Conclusion}

The model of the margin evolution presented here shows that the southwestern coast of Angola has evolved in a polycyclic pattern during the Late Phanerozoic, implying that this margin segment may not be interpreted as purely "passive". Therefore, the currently proximal domain of the Namibe Angolan margin probably was covered by sediments from before, during and after rifting, which were eroded following succeeding exhumation events.

In the same way that modern models have demonstrated that rifting to breakup processes are marked by a succession of complex events, we show that the proximal domain of the Namibe margin, theoretically defined as being less or unaffected by crustal stretching, may also have had a complex evolution. This approach opens the possibility that the processes related to extension and thinning during rifting, which are characteristic of the sag and distal domains, may also occur in the proximal domain of the margin and influence its rift- to post-rift evolution. In the same way, the mantle processes may have been of fundamental importance during rifting to post-rift times, whether directly or indirectly. The interaction between mantle dynamics, tectonic processes, and climate seems to have been essential during the Cenozoic evolution of the Namibe margin, accounting for the pronounced Oligocene-Miocene exhumation.

The combined AFT and AHe modeling coupled with geological information provides a helpful strategy for the interpretation of the events that control the passive margins evolution. Furthermore, robust thermal histories could elucidate the geological evolution of regions that mostly lack current geological and stratigraphic markers, such as the inland domain of the Namibe Angolan margin. We believe that this integration is a fundamental approach, able to provide the correct foundation to elucidate how continental margins evolve.

Acknowledgements Acknowledgements are given to the National Council of Scientific and Technological Development (CNPq) for the scholarship and to Elton Luiz Dantas for using the SELFRAG laboratory at the University of Brasilia, Brazil. We also acknowledge the Faculty of Natural Sciences of Agostinho Neto University, Angola, for their support during fieldwork and the Institute of Earth Sciences at the Heidelberg University, Germany, for the preparation of the samples for AFT analysis. We are also grateful to Paul F. Green and anonymous reviewer for their constructive comments and important improvements on the manuscript.

\section{References}

Al-hajri Y, White N, Fishwick S (2009) Scales of transient convective support beneath Africa. Geology. https://doi.org/10.1130/ G25703A.1

Araújo AG, Guimarães F (1992) Geologia de Angola. Notícia explicativa da carta geológica à escala 1:1000000 137

Aslanian D, Moulin M, Olivet JL et al (2009) Brazilian and African passive margins of the Central Segment of the South Atlantic Ocean: kinematic constraints. Tectonophysics 468:98-112. https://doi.org/10.1016/j.tecto.2008.12.016

Babonneau N, Savoye B, Cremer M, Bez M (2010) Sedimentary Architecture in Meanders of a Submarine Channel: detailed Study of the Present Congo Turbidite Channel (Zaiango Project). J Sediment Res 80:852-866. https://doi.org/10.2110/ jsr.2010.078

Bache F, Leroy S, Baurion C et al (2011) Post-rift uplift of the Dhofar margin (Gulf of Aden). Terra Nova 23:11-18. https://doi. org/10.1111/j.1365-3121.2010.00975.x

Beglinger SE, Doust H, Cloetingh S (2012) Relating petroleum system and play development to basin evolution: West African South Atlantic basins. Mar Pet Geol 30:1-25. https://doi. org/10.1016/j.marpetgeo.2011.08.008

Behrmann JH, Shulgin A, Prokoph A (2011) High Resolution Bathymetric Survey on the NW Slope of Walvis Ridge, Offshore Namibia. Ber Naturf Ges Freiburg i Br 101:97-110

Binks RM, Fairhead JD (1992) A plate tectonic setting for Mesozoic rifts of West and Central Africa. Tectonophysics 213:141-151

Blaich OA, Faleide JI, Tsikalas F (2011) Crustal breakup and continent-ocean transition at South Atlantic conjugate margins. J Geophys Res Solid Earth 116:1-38. https://doi. org/10.1029/2010JB007686

Bott MHP (1995) Mechanisms of rifting: Geodynamic modeling of continental rift systems. In: Olsen KH (ed) Continental rifts. evolution, structure, tectonics, 466. Elsevier, New York

Brown RW, J. RD A, SM et al (1990) An Early Cretaceous phase of accelerated erosion on the South-Western margin of Africa: evidence from apatite fission track analysis and the offshore sedimentary record. Nucl Tracks Radiat Meas 17:339-350

Brown R, Gallagher K, Duane M (1994) A quantitative assessment of the effects of magmatism on the thermal history of the Karoo sedimentary sequence. J Afr Earth Sc 18:227-243

Brown RW, Summerfield MA, Gleadow AJW (2002) Denudational history along a transect across the Drakensberg Escarpment of southern Africa derived from apatite fission track thermochronology. J Geophys Res 107:2350. https://doi. org/10.1029/2001JB000745 
Brown RW, Beucher R, Roper S et al (2013) Natural age dispersion arising from the analysis of broken crystals. Part I: Theoretical basis and implications for the apatite ( $\mathrm{U}-\mathrm{Th}) / \mathrm{He}$ thermochronometer. Geochimica et Cosmochimica Acta. https://doi. org/10.1016/j.gca.2013.05.041

Brown R, Summerfield M, Gleadow A et al (2014) Intracontinental deformation in southern Africa during the Late Cretaceous. J Afr Earth Sc 100:20-41. https://doi.org/10.1016/j.jafrearsci. 2014.05.014

Brune S, Heine C, Pérez-Gussinye M, Sobolev SV (2014) Rift migration explains continental margin asymmetry and crustal hyperextension. Nat Commun. https://doi.org/10.1038/ncomms5014

Brune S, Heine C, Clift PD, Perez-Gussiny M (2017) Rifted margin architecture and crustal rheology: reviewing Iberia-Newfoundland, Central South Atlantic, and South China Sea. Mar Pet Geol 79:257-281. https://doi.org/10.1016/j.marpetgeo.2016.10.018

Buck WR (1986) Small-scale convection induced by passive rifting: the cause for uplift of rift shoulders. Earth Planet Sci Lett 77:362-372

Bunge H-P, Glasmacher UA (2018) Models and observations of vertical motion (MoveOn) associated with rifting to passive margins: Preface. Gondwana Res 53:1-8

Burke K (1996) The African plate. S Afr J Geol 99:341-409

Burov E, Cloetingh S (1997) Erosion and rift dynamics: new thermomechanical aspects of post-rift evolution of extensional basins. Earth Planet Sci Lett 150:7-26

Carlson WD, Donelick RA, Ketcham RA (1999) Variability of apatite fission-track annealing kinetics: I. Experimental results. Am Miner 84:1213-1223. https://doi.org/10.2138/am-1999-0901

Casciello E, Vergés J, Cruz I et al (2016) Structural and Stratigraphic Study of the Namibe Basin (Angola). In: AAPG annual convention and exhibition. Calgary, Alberta

Catuneanu O, Wopfner H, Eriksson PG et al (2005) The Karoo basins of south-central Africa. J Afr Earth Sc 43:211-253. https://doi. org/10.1016/j.jafrearsci.2005.07.007

Clerc C, Ringenbach J, Jolivet L, Ballard J (2018) Rifted margins: ductile deformation, boudinage, continentward-dipping normal faults and the role of the weak lower crust. Gondwana Res 53:20-40. https://doi.org/10.1016/j.gr.2017.04.030

Cockburn HAP, Brown RW, Summerfield MA, Seidl MA (2000) Quantifying passive margin denudation and landscape development using a combined fission-track thermochronology and cosmogenic isotope analysis approach. Earth Planet Sci Lett 179:429435. https://doi.org/10.1016/S0012-821X(00)00144-8

Colli L, Stotz I, Bunge HP et al (2014) Rapid South Atlantic spreading changes and coeval vertical motion in surrounding continents: evidence for temporal changes of pressure-driven upper mantle flow. Tectonics 33:1304-1321. https://doi.org/10.1002/2014T C003612

Colli L, Ghelichkhan S, Bunge H, Oeser J (2018) Retrodictions of Mid Paleogene mantle fl ow and dynamic topography in the Atlantic region from compressible high resolution adjoint mantle convection models: sensitivity to deep mantle viscosity and tomographic input model. Gondwana Res 53:252-272. https:// doi.org/10.1016/j.gr.2017.04.027

Contrucci I, Matias L, Moulin M et al (2004) Deep structure of the West African continental margin (Congo, Zarre, Angola), between $5^{\circ} \mathrm{S}$ and $8{ }^{\circ} \mathrm{S}$, from reflection/refraction seismics and gravity data. Geophys J Int 158:529-553. https://doi.org/10.1111/ j.1365-246X.2004.02303.x

Dafoe LT, Keen CE, Dickie K, Williams GL (2017) Regional stratigraphy and subsidence of Orphan Basin near the time of breakup and implications for rifting processes. Basin Res 29:233-254. https://doi.org/10.1111/bre.12147

De Waele B, Johnson SP, Pisarevsky SA (2008) Palaeoproterozoic to Neoproterozoic growth and evolution of the eastern Congo
Craton: its role in the Rodinia puzzle. Precambr Res 160:127141. https://doi.org/10.1016/j.precamres.2007.04.020

De Vera J, Granado P, McClay K (2010) Structural evolution of the Orange Basin gravity-driven system, offshore Namibia. Mar Pet Geol 27:223-237. https://doi.org/10.1016/j.marpe tgeo.2009.02.003

Dinis PA, Callapez PM, Dinis JL, Alberto A (2010) A Campanian (?) Gilbert delta from Namibe (Angola). Preliminary data on outstanding exposures. Geosci On-line J 21:1-4

Donelick RA, O'Sullivan PB, Ketcham RA (2005) Apatite FissionTrack Analysis. Rev Mineral Geochem 58:49-94. https://doi. org/10.2138/rmg.2005.58.3

Dressel I, Scheck-Wenderoth M, Cacace M, Reichert C (2015) Reconstruction of the southwestern African continental margin by backward modeling. Mar Pet Geol 67:544-555. https://doi. org/10.1016/j.marpetgeo.2015.06.006

Dressel I, Cacace M, Scheck-wenderoth M (2016) Coupled thermomechanical 3D subsidence analysis along the SW African passive continental margin. Arab J Geosci. https://doi.org/10.1007/ s12517-016-2407-9

Dressel I, Scheck-wenderoth M, Cacace M (2017) Tectonophysics Backward modelling of the subsidence evolution of the Colorado Basin, offshore Argentina and its relation to the evolution of the conjugate Orange Basin, offshore SW Africa. Tectonophysics 716:168-181. https://doi.org/10.1016/j.tecto.2016.08.007

Eales HV, Marsh JS, Cox KG (1984) The Karoo igneous province: an introduction. In: Erlank, AJ (ed) Petrogenesis of the volcanic rocks of the karoo province. Special Publication, vol 13. Geological Society of South Africa, Johannesburg, p 395

Ebinger CJ, Bechtel TD, Forsyth DW, Bowin CO (1989) Effective elastic plate thickness beneath the East African and Afar plateaus and dynamic compensation of the uplifts. J Geophys Res 94:2883-2901

Ehlers TA, Farley KA (2003) Apatite (U-Th)/He thermochronometry: methods and applications to problems in tectonic and surface processes. Earth Planetary Science Letters 206:1-14. https://doi. org/10.1016/S0012-821X(02)01069-5

Farley KA, Wolf RA, Silver LT (1996) The effects of long alpha-stopping distances on (U-Th)/He ages. Geochim Cosmochim Acta 60:4223-4229. https://doi.org/10.1016/S0016-7037(96)00193-7

Flowers RM, Kelley SA (2011) Interpreting data dispersion and "inverted" dates in apatite (U-Th)/He and fission-track datasets: an example from the US midcontinent. Geochim Cosmochim Acta 75:5169-5186. https://doi.org/10.1016/j.gca.2011.06.016

Flowers RM, Schoene B (2010) (U-Th)/He thermochronometry constraints on unroofing of the eastern Kaapvaal craton and significance for uplift of the southern African plateau. Geology 38:827-830. https://doi.org/10.1130/G30980.1

Flowers RM, Ketcham RA, Shuster DL, Farley KA (2009) Apatite (U-Th)/He thermochronometry using a radiation damage accumulation and annealing model. Geochim Cosmochim Acta 73:2347-2365. https://doi.org/10.1016/j.gca.2009.01.015

Franke D (2013) Rifting, lithosphere breakup and volcanism: comparison of magma-poor and volcanic rifted margins. Mar Pet Geol 43:63-87. https://doi.org/10.1016/j.marpetgeo.2012.11.003

Friedrich AM, Bunge H, Rieger SM et al (2018) Stratigraphic framework for the plume mode of mantle convection and the analysis of interregional unconformities on geological maps. Gondwana Res 53:159-188. https://doi.org/10.1016/j.gr.2017.06.003

Galbraith RF (1981) On statistical models for fission track counts. J Inter Assoc Math Geo 13(6):471-478

Gallagher K (2012) Transdimensional inverse thermal history modeling for quantitative thermochronology. J oGeophys Res Solid Earth 117:1-16. https://doi.org/10.1029/2011JB008825

Gallagher K, Brown RW (1997) The onshore record of passive margin evolution. J Geol Soc 154:451-457. https://doi.org/10.1144/gsjgs. 154.3.0451 
Gallagher K, Brown R (1999) Denudation and uplift at passive margins: the record on the Atlantic Margin of southern Africa. Philos Trans R Soc A Math Phys Eng Sci 357:835-859. https://doi. org/10.1098/rsta.1999.0354

Gallagher K, Brown R, Johnson C (1998) Fission track analysis and its applications to geological problems. Annual Rev Earth Planet Sci 26(1):519-572

Gallagher K, Charvin K, Nielsen S et al (2009) Markov chain Monte Carlo (MCMC) sampling methods to determine optimal models, model resolution and model choice for Earth Science problems. Mar Pet Geol 26:525-535. https://doi.org/10.1016/j.marpe tgeo.2009.01.003

Gautheron C, Tassan-got L, Barbarand J, Pagel M (2009) Effect of alpha-damage annealing on apatite (U-Th)/ He thermochronology. Chem Geol 266:157-170. https://doi.org/10.1016/j.chemg eo.2009.06.001

Gautheron C, Barbarand J, Ketcham RA et al (2013) Chemical in fl uence on $\alpha$-recoil damage annealing in apatite: implications for (U-Th)/ He dating. Chem Geol 351:257-267. https://doi. org/10.1016/j.chemgeo.2013.05.027

Gindre-Chanu L, Warren JK, Puigdefabregas C et al (2015) Diagenetic evolution of aptian evaporites in the namibe basin (south-west Angola). Sedimentology 62:204-233. https://doi.org/10.1111/ sed.12146

Gindre-Chanu L, Perri E, Sharp R. I et al (2016) Origin and diagenetic evolution of gypsum and microbialitic carbonates in the Late Sag of the Namibe Basin (SW Angola). Sed Geol 342:133-153. https ://doi.org/10.1016/j.sedgeo.2016.06.015

Giresse P, Hoang C-T, Kouyoumontzakis G (1984) Analysis of vertical movements deduced from a geochronological study of marine Pleistocene deposits, southern coast of Angola. J Afr Earth Sci 2:177-187. https://doi.org/10.1016/S0731-7247(84)80012-9

Gleadow AJW (1981) Fission-track dating methods: what are the real alternatives? Nuclear Tracks 5:3-14. https://doi. org/10.1016/0191-278X(81)90021-4

Green PF (1981) A new look at statistics in fission-track dating. Nuclear Tracks 5:77-86. https://doi.org/10.1016/0191-278X(81)90029-9

Green PF, Machado V (2015) Pre-rift and synrift exhumation, postrift subsidence and exhumation of the onshore Namibe Margin of Angola revealed from apatite fission track analysis. Geol Soc Lond Spec Publ. https://doi.org/10.1144/SP438.2

Green P, Swart R, Jacob J et al (2009) Thermochronology and landscape development in Southern Africa. In: PESGB/HGS Africa Meeting, London

Green PF, Duddy IR, Japsen P et al (2015) Post-breakup burial and exhumation of the southern margin of Africa. Basin Res. https:// doi.org/10.1111/bre.12167

Green PF, Japsen P, Chalmers JA et al (2018) Post-breakup burial and exhumation of passive continental margins: seven propositions to inform geodynamic models. Gondwana Res 53:58-81. https:// doi.org/10.1016/j.gr.2017.03.007

Gröger HR, Machado V, Pinto G Di (2013) Uplift, exhumation and erosion along the Angolan continental margin : an integrated approach. In: EGU General Assembly Conference Abstracts. Vienna, Austria, p 8711

Guillocheau F, Rouby D, Robin C et al (2012) Quantification and causes of the terrigeneous sediment budget at the scale of a continental margin: a new method applied to the Namibia-South Africa margin. Basin Res 24:3-30. https://doi.org/10.1111/j.1365-2117.2011.00511.x

Guillocheau F, Simon B, Baby G et al (2018) Planation surfaces as a record of mantle dynamics: the case example of Africa. Gondwana Res 53:82-98. https://doi.org/10.1016/j.gr.2017.05.015

Guiraud R, Bosworth W (1997) Senonian basin inversion and rejuvenation of rifting in Africa and Arabia: synthesis and implications to plate-scale tectonics. Tectonophysics 282:39-82. https://doi. org/10.1016/S0040-1951(97)00212-6
Guiraud M, Buta-Neto A, Quesne D (2010) Segmentation and differential post-rift uplift at the Angola margin as recorded by the transform-rifted Benguela and oblique-to-orthogonal-rifted Kwanza basins. Mar Pet Geol 27:1040-1068. https://doi.org/10.1016/j. marpetgeo.2010.01.017

Hudec MR, Jackson MPA (2002) Structural segmentation, inversion, and salt tectonics on a passive margin: evolution of the Inner Kwanza Basin, Angola. Bull Geol Soc Am 114:1222-1244. https://doi.org/10.1130/0016-7606(2002)114\%3C1222:SSIAS T\%3E2.0.CO;2

Huismans R, Beaumont C (2011) Depth-dependent extension, twostage breakup and cratonic underplating at rifted margins. Nature 473:74-78. https://doi.org/10.1038/nature09988

Huismans RS, Beaumont C (2014) Rifted continental margins: the case for depth-dependent extension. Earth Planet Sci Lett 407:148162. https://doi.org/10.1016/j.eps1.2014.09.032

Jackson MPA, Hudec MR, Hegarty KA (2005) The great West African Tertiary coastal uplift: fact or fiction? A perspective from the Angolan divergent margin. Tectonics. https://doi. org/10.1029/2005TC001836

Japsen P, Bonow JM, Green PF et al (2006) Elevated, passive continental margins: long-term highs or Neogene uplifts? New evidence from West Greenland. Earth Planet Sci Lett 248:315-324. https ://doi.org/10.1016/j.epsl.2006.05.036

Jerram D, Mountney N, Holzförster F, Stollhofen H (1999) Internal stratigraphic relationships in the Etendeka Group in the Huab Basin, NW Namibia: Understanding the onset of flood volcanism. J Geodyn 28:393-418. https://doi.org/10.1016/S0264 -3707(99)00018-6

Johnson MR, Van Vuuren CJ, Hegenberger WF et al (1996) Stratigraphy of the Karoo Supergroup in southern Africa: an overview. J Afr Earth Sc 23:3-15. https://doi.org/10.1016/S0899 $-5362(96) 00048-6$

Jung S, Mezger K (2001) Geochronology in migmatites-a Sm-Nd, $\mathrm{U}-\mathrm{Pb}$ and $\mathrm{Rb}-\mathrm{Sr}$ study from the Proterozoic Damara belt (Namibia): implications for polyphase development of migmatites in high-grade terranes. J Metamorph Geol 19:77-97. https:// doi.org/10.1046/j.0263-4929.2000.00297.x

Ketcham RA, Carter A, Donelick RA et al (2007a) Improved measurement of fission-track annealing in apatite using c-axis projection. Am Miner 92:789-798. https://doi.org/10.2138/am.2007.2280

Ketcham RA, Carter A, Donelick RA et al (2007b) Improved modeling of fission-track annealing in apatite. Am Miner 92:799-810. https ://doi.org/10.2138/am.2007.2281

Ketcham RA, Gautheron C, Tassan-Got L (2011) Accounting for long alpha-particle stopping distances in (U-Th-Sm)/He geochronology: refinement of the baseline case. Geochim Cosmochim Acta 75:7779-7791. https://doi.org/10.1016/j.gca.2011.10.011

Ketcham RA, Carter A, Hurford A (2015) Inter-laboratory comparison of fission track confined length and etch figure measurements in apatite. Am Miner 100:1452-1468

Koch C, Coole P (2014) Regional Prospectivity of Offshore Namibia and the Angolan Namibe Basin. In: 76th EAGE international conference \& exhibition. AAPG Datapages Search and Discovery, pp 14-17

Kounov A, Viola G, de Wit M, Andreoli MAG (2009) Denudation along the Atlantic passive margin: new insights from apatite fission-track analysis on the western coast of South Africa. Geol Soc Lond Spec Publ 324:287-306. https://doi.org/10.1144/ SP324.19

Kroner A (1982) Rb/Sr geochronology and tectonic evolution of the Pan-African Damara Belt of Namibia, southwestern Africa. Am J Sci 282:1471-1507. https://doi.org/10.2475/ajs.282.9.1471

Kukla PA, Strozyk F, Mohriak WU (2018) South Atlantic salt basins Witnesses of complex passive margin evolution. Gondwana Res 53:41-57. https://doi.org/10.1016/j.gr.2017.03.012 
Lavier LL, Steckler MS, Brigaud F (2001) Climatic and tectonic control on the Cenozoic evolution of the West African margin. Mar Geol 178:63-80. https://doi.org/10.1016/S0025-3227 (01)00175-X

Lentini MR, Fraser SI, Sumner HS, Davies RJ (2010) Geodynamics of the central South Atlantic conjugate margins: implications for hydrocarbon potential. Pet Geosc 16:217-229. https://doi. org/10.1144/1354-079309-909

Lithgow-Bertelloni C, Silver P (1998) Dynamic topography, plate driving forces and the African superswell. Nature 395:345-348. https ://doi.org/10.1038/26212

Lundin E, Doré AG (2002) Mid-Cenozoic post-breakup deformation in the 'passive $\hat{a} €^{\mathrm{TM}}$ margins bordering the Norwegian \pm Greenland Sea. Mar Pet Geol 19:79-93

Macgregor DS (2010) Understanding African and Brazilian margin climate, topography and drainage systems, implications for predicting deepwater reservoirs and source rock burial history. AAPG, Search and Discovery Article, 10270. http://www.searc handdiscovery.net/documents/2010/10270macgregor/ndx_macgr egor.pdf

Macgregor DS (2013) Late Cretaceous-Cenozoic sediment and turbidite reservoir supply to South Atlantic margins. Geol Soc Lond Spec Publ 369:109-128. https://doi.org/10.1144/SP369.7

Manatschal G (2004) New models for evolution of magma-poor rifted margins based on a review of data and concepts from West Iberia and the Alps. Int J Earth Sci. https://doi.org/10.1007/s0053 1-004-0394-7

Marsh JS, Milner SC (2007) Stratigraphic correlation of the Awahab and Tafelberg Formations, Etendeka Group, Namibia, and location of an eruptive site for flood basalt volcanism. J Afr Earth Sci 48:329-340. https://doi.org/10.1016/j.jafrearsci.2007.04.004

Marsh JS, Swart R (2016) The Bero Volcanic Complex: extension of the Paraná-Etendeka Igneous Province into SW Angola. J Volcanol Geothermal Res. https://doi.org/10.1016/j.jvolgeores. 2016.10.011

Masini E, Manatschal G, Tugend J et al (2014) The tectono-sedimentary evolution of a hyper - extended rift basin: the example of the Arzacq-Mauléon rift system (Western Pyrenees, SW France). Int J Earth Sci. https://doi.org/10.1007/s00531-014-1023-8

Maslanyj MP, Light MPR, Greenwood RJ, Banks NL (1992) Extension tectonics offshore Namibia and evidence for passive rifting in the South Atlantic. Mar Pet Geol 9:590-601. https://doi. org/10.1016/0264-8172(92)90032-A

Maystrenko YP, Scheck-Wenderoth M, Hartwig A et al (2013) Structural features of the Southwest African continental margin according to results of lithosphere-scale 3D gravity and thermal modelling. Tectonophysics 604:104-121. https://doi. org/10.1016/j.tecto.2013.04.014

Mazur S, Quallington A, Parker S et al (2016) Benguela and Namibe Basins: Syn-Rift Architecture and Sediment Thickness From Integrated Analysis of Aeromagnetic Data. In: AAPG Annual Convention and Exhibition. Calgary, Alberta

McCourt S, Armstrong R, Jelsma H, Mapeo RBM (2013) New U-Pb SHRIMP ages from the Lubango region, SW Angola: insights into the Palaeoproterozoic evolution of the Angolan Shield, southern Congo Craton, Africa. J Geol Soc 170:353-363. https:// doi.org/10.1144/jgs2012-059.New

McKenzie D (1978) Some remarks on the development of sedimentary basins. Earth Planet Sci Lett 40:25-32. https://doi. org/10.1016/0012-821X(78)90071-7

Menges D, Karl M, Glasmacher UA (2013) Thermal history and evolution of the South Atlantic passive continental margin in northern Namibia. In: EGU General Assembly Conference Abstracts. p 658

Milani EJ, De Wit MJ (2008) Correlations between the classic Paraná and Cape-Karoo sequences of South America and southern
Africa and their basin infills flanking the Gondwanides: du Toit revisited. Geol Soc Lond Spec Publ 294:319-342. https://doi. org/10.1144/SP294.17

Miller RM (1997) The Owambo Basin of Northern Namibia. In: Selley RC (ed) African basins. Sedimentary basins of the world, 3rd edn. Elsevier Science, Amsterdam, pp 237-268

Mohriak W, Nemc M, Enciso G (2008) South Atlantic divergent margin evolution: rift-border uplift and salt tectonics in the basins of SE Brazil. Geol Soc Lond Spec Publ 294:365-398. https://doi. org/10.1144/SP294.19

Moulin M, Fluteau F, Courtillot V et al (2017) Eruptive History of the Karoo lava flows and their impact on Early Jurassic environmental change. J Geophys Res 122:738-772. https://doi. org/10.1002/2016JB013354

Müller RD, Hassan R, Gurnis M et al (2018) Dynamic topography of passive continental margins and their hinterlands since the Cretaceous. Gondwana Res 53:225-251. https://doi.org/10.1016/j. gr.2017.04.028

Mvondo F, Dauteuil O, Guillocheau F (2011) The Fish River canyon (Southern Namibia): a record of Cenozoic mantle dynamics? Comptes Rendus Geosci 343:478-485. https://doi.org/10.1016/j. crte.2011.07.003

Nyblade AA, Robinson SW (1994) The African Superswell. Geophys Res Lett 21:765-768. https://doi.org/10.1029/94GL00631

O'Connor J, Jokat W, Wijbrans J, Colli L (2018) Hotspot tracks in the South Atlantic located above bands of fast flowing asthenosphere driven by waning pulsations from the African LLSVP. Gondwana Res 53:197-208. https://doi.org/10.1016/j.gr.2017.05.014

Péron-Pinvidic G, Manatschal G (2008) The final rifting evolution at deep magma-poor passive margins from Iberia-Newfoundland: a new point of view. Int J Earth Sci. https://doi.org/10.1007/s0053 1-008-0337-9

Porchetti SD, Wagensommer A (2015) A vertebrate trackway from the Twyfelfontein Formation (Lower Cretaceous), Damaraland, Namibia. Paläontologische Zeitschrift 89:807-814. https://doi. org/10.1007/s12542-015-0264-6

Raab MJ, Brown RW, Gallagher K et al (2002) Late Cretaceous reactivation of major crustal shear zones in northern Namibia: constraints from apatite fission track analysis. Tectonophysics 349:75-92. https://doi.org/10.1016/S0040-1951(02)00047-1

Reid W, Ashfield A (2016) The Namibe Basin: A Clearer Image. GeoExpro article, vol. 13, No. 5. https://www.geoexpro.com/artic les/2016/12/the-namibe-basin-a-clearer-image

Reiners PW, Farley KA (2001) Influence of crystal size on apatite (U-Th)/He thermochronology: an example from the Bighorn Mountains, Wyoming. Earth Planet Sci Lett 188:413-420. https:// doi.org/10.1016/S0012-821X(01)00341-7

Renne PR, Glen JM, Milner SC, Duncan AR (1996) Age of Etendeka flood volcanism and associated intrusions in southwestern Africa. Geology 24:659-662. https://doi.org/10.1130/00917613(1996)024\%3C0659:AOEFVA\%3E2.3.CO;2

Reston TJ (2009) The structure, evolution and symmetry of the magmapoor rifted margins of the North and Central Atlantic : a synthesis. Tectonophysics 468:6-27. https://doi.org/10.1016/j.tecto 2008.09.002

Roberts GG, White N (2010) Estimating uplift rate histories from river profiles using African examples. J Geophys Res Solid Earth 115:1-24. https://doi.org/10.1029/2009JB006692

Rogers JJW, Santosh M (2004) Continents and Supercontinents. Oxford University Press, Inc, New York

Rowan MG (2014) Passive-margin salt basins: hyperextension, evaporite deposition, and salt tectonics. Basin Res. https://doi. org/10.1111/bre.12043

Ryan WBF, Carbotte SM, Coplan JO et al (2009) Global MultiResolution Topography synthesis. Geochem Geophys Geosyst 10:Q03014. https://doi.org/10.1029/2008GC002332 
Scherer CMS (2000) Eolian dunes of the Botucatu Formation (Cretaceous) in southernmost Brazil: morphology and origin. Sed Geol 137:63-84. https://doi.org/10.1016/S0037-0738(00)00135-4

Scotese CR (2000) Paleomap Project, Climate History. http://www. scotese.com/climate.htm. Accessed 5 Dec 2016

Séranne M, Anka Z (2005) South Atlantic continental margins of Africa: a comparison of the tectonic vs climate interplay on the evolution of equatorial west Africa and SW Africa margins. J Afr Earth Sc 43:283-300. https://doi.org/10.1016/j.jafrearsci.2005.07.010

Spiegel C, Kohn B, Belton D et al (2009) Apatite (U-Th-Sm)/He thermochronology of rapidly cooled samples: the effect of $\mathrm{He}$ implantation. Earth Planet Sci Lett 285:105-114. https://doi. org/10.1016/j.epsl.2009.05.045

Stollhofen H, Stanistreet IG, Von Hagke C, Nguno A (2014) PliocenePleistocene climate change, sea level and uplift history recorded by the Horingbaai fan-delta, NW Namibia. Sed Geol 309:15-32. https://doi.org/10.1016/j.sedgeo.2014.05.008

Strganac C, Salminen J, Jacobs LL et al (2014) Carbon isotope stratigraphy, magnetostratigraphy, and ${ }^{40} \mathrm{Ar} /{ }^{39} \mathrm{Ar}$ age of the Cretaceous South Atlantic coast, Namibe Basin, Angola. J Afr Earth Sc 99:452-462. https://doi.org/10.1016/j.jafrearsci.2014.03.003

Strozyk F, Back S, Kukla PA (2016) Comparison of the rift and postrift architecture of conjugated salt and salt-free basins offshore Brazil and Angola / Namibia, South Atlantic. Tectonophysics. https://doi.org/10.1016/j.tecto.2016.12.012

Svartman Dias AE, Hayman NW, Lavier LL (2016) Thinning factor distributions viewed through numerical models of continental extension. Tectonics 35:3050-3069. https://doi. org/10.1002/2016TC004266

Svensen H, Corfu F, Polteau S et al (2012) Rapid magma emplacement in the Karoo Large Igneous Province. Earth Planet Sci Lett 325-326:1-9. https://doi.org/10.1016/j.eps1.2012.01.015

Tinker J, de Wit M, Brown R (2008) Mesozoic exhumation of the southern Cape, South Africa, quantified using apatite fission track thermochronology. Tectonophysics 455:77-93. https://doi. org/10.1016/j.tecto.2007.10.009

Torsvik TH, Rousse S, Labails C, Smethurst MA (2009) A new scheme for the opening of the South Atlantic Ocean and the dissection of an Aptian salt basin. Geophys J Int 177:1315-1333. https://doi. org/10.1111/j.1365-246X.2009.04137.X

Turner JP, Green PF, Holford SP, Lawrence SR (2008) Thermal history of the Rio Muni (West Africa)-NE Brazil margins during continental breakup. Earth Planet Sci Lett 270:354-367. https:// doi.org/10.1016/j.epsl.2008.04.002

Van Der Beek P, Cloetingh S, Andriessen P (1994) Mechanisms of extensional basin formation and vertical motions at rift flanks: constraints from tectonic modelling and fission-track thermochronology. Earth Planet Sci Lett 121:417-433

Van Der Beek P, Summerfield MA, Braun J et al (2002) Modeling postbreakup landscape development and denudational history across the southeast African (Drakensberg Escarpment) margin. J Geophys Res 107:2351. https://doi.org/10.1029/2001JB000744

Vermeesch P, Seward D, Latkoczy C, Wipf M (2007) a -Emitting mineral inclusions in apatite, their effect on $(\mathrm{U}-\mathrm{Th}) / \mathrm{He}$ ages, and how to reduce it. Geochim Cosmochim Acta 71:1737-1746. https:// doi.org/10.1016/j.gca.2006.09.020

Walker RT, Telfer M, Kahle RL et al (2016) Rapid mantle-driven uplift along the Angolan margin in the late Quaternary. Nat Geosci 9:909-914. https://doi.org/10.1038/ngeo2835

Weissel JK, Karner GD (1989) Flexural uplift of rift flanks due to mechanical unloading of the lithosphere during extension. J Geophys Res 94:13919-13950

Wernicke B (1985) Uniform-sense normal simple shear of the continental lithosphere. Canad J Earth Sci 22:108-125

Whitmarsh RB, Manatschal G, Minshull TA (2001) Evolution of magma-poor continental margins from rifting to seafloor spreading. Nature 413:150-154

Wildman M, Brown R, Watkins R et al (2015) Post break-up tectonic inversion across the southwestern cape of South Africa: new insights from apatite and zircon fission track thermochronometry. Tectonophysics 654:30-55. https://doi.org/10.1016/j.tecto. 2015.04.012

Wildman M, Brown R, Beucher R et al (2016) The chronology and tectonic style of landscape evolution along the elevated Atlantic continental margin of South Africa resolved by joint apatite fission track and (U-Th-Sm)/He thermochronology. Tectonics 35:511-545. https://doi.org/10.1002/2015TC004042

Wu S, Gao J, Zhao S et al (2014) Post-rift uplift and focused fluid flow in the passive margin of northern South China Sea. Tectonophysics 616:27-39. https://doi.org/10.1016/j.tecto.2013.12.013

Ziegler PA, Cloetingh S (2004) Dynamic processes controlling evolution of rifted basins. Earth Sci Rev 64:1-50. https://doi. org/10.1016/S0012-8252(03)00041-2 